\title{
Unravelling the internal architecture of the Alnö alkaline and carbonatite complex (central Sweden) using 3D models of gravity and magnetic data
}

\author{
Magnus Andersson and Alireza Malehmir \\ Department of Earth Sciences, Uppsala University, Villavägen 16, SE-75236, Uppsala, Sweden. \\ Correspondence to: Magnus Andersson (magnus.andersson@geo.uu.se)
}

\begin{abstract}
The Alnö complex in central Sweden is one of the largest alkaline and carbonatite ring-shaped intrusions in the world. Presented here is the 3D inversion of ground gravity and aeromagnetic data that confirms some of the previous ideas about the 3D geometry of the complex but also suggests that the complex may continue laterally further to north than earlier expected. The gravity and aeromagnetic data show the complex as (i) a strong positiver Bouguer anomaly, around $20 \mathrm{mGal}$,

5 one of the strongest gravity gradients observed in Sweden, and (ii) a strong positive magnetic anomaly, exceeding $2000 \mathrm{nT}$. Magnetic structures are clearly discernible within the complex and surrounding area. Petrophysical measurements (density, bulk magnetic susceptibility, and magnetic remanence) were used to constrain the $3 \mathrm{D}$ inversion. Both gravity and magnetic inversion models suggest that dense $\left(>2850 \mathrm{~kg} / \mathrm{m}^{3}\right)$ and magnetic $(>0.05 \mathrm{SI})$ rocks extend down to about $3.5-4 \mathrm{~km}$ depth. Previous studies have suggested a solidified magma reservoir at this approximate depth. The inversion models further suggest that two apparently separate regions within the intrusion with gravity and magnetic highs are likely connected at depth, starting from 800-1000 m, implying a common source for the rocks observed in these two regions. The modelling of the aeromagnetic data indicates that a more than $3 \mathrm{~km}$ wide ring-shaped magnetic high in the bay that can be a hidden part of the complex, linking a satellite intrusion in Söråker on the northern side of the bay to the main intrusion on the Alnö Island. While the rim of the ring must consist of highly susceptible rocks to support the magnetic anomaly, the centre has a relatively low magnetisation and is probably made up of low-susceptible wall-rocks or metasomatised wall-rocks down to about $2 \mathrm{~km}$. Below this depth the 3D susceptibility model shows higher magnetic susceptibility values. From these observations the solidified magma chamber is interpreted to extend further to north than has previously been suggested.
\end{abstract}

\section{Introduction}

Although alkaline and carbonatite rocks make up a small portion of the crust's volume, they are found in all continents, various geological settings and emplaced during various geological periods, from Archaean to the present-day (Treiman and Schedl, 1983; Le Bas, 1987; Berger et al., 2009). The only carbonatite volcano that have been recorded to be active in the modern time is the Oldoinyo Lengai located in the East African Rift in northern Tanzania (e.g., Dawson, 1962; Dawson et al., 1990; Woolley and Church, 2005; Mattsson and Vuorinen, 2008). The Alnö complex, located to the south of Klingefjärden bay on the northern part of Alnö Island (Figure 1), was one of the first carbonatite and alkaline localities to be described and has since 
Solid Earth Discuss., doi:10.5194/se-2017-3, 2017

Manuscript under review for journal Solid Earth

Published: 23 January 2017

(c) Author(s) 2017. CC-BY 3.0 License.

then been extensively studied (e.g., Högbom, 1895; von Eckermann, 1948; Kresten, 1980, 1990; Vuorinen, 2005; Meert et al., 2007; Skelton et al., 2007). Despite its unique geology and global significance, the projection of surface geological data have until recently been the main source of information to shed light on the deeper structures (e.g., von Eckermann, 1948; Kresten, 1980, 1990; Mattsson et al., 2014). Kresten (1980) suggested the presence of a shallow magma chamber on the basis of 2D projections using measurements of dip and dip direction of alkaline and carbonatite sheet intrusions and concluded that the Alnö intrusion was emplaced in two stages. Boulders with carbonatite breccia and accretionary lapilli fragments have been found at Sälskär skerries (von Eckermann, 1960), and was suggested by Kresten (1990) to relate to surface or near-surface volcanic activity.

The complex is characterised by a strong gravity $(>20 \mathrm{mGal})$ and magnetic high on the northern part of the Alnö Island. However geophysical anomalies are also observed at its immediate margins to the north, on some smaller islands and on the northern side of the Klingefjärden bay. The bay also features a ring-shaped magnetic structure (Figure $2 b$ ). There is still no concrete evidence (e.g., from deep boreholes) connecting the structures observed on the Alnö Island with the magnetic ringshaped structure in the bay. Using a combination of reflection seismic data, surface geological studies and the presence of large accretionary lapilli blocks found in Sälskär skerries (Figure 1) Andersson et al. (2013) also suggested the possibility of a shallow fossil magma chamber at around 3-4 km depth, indicated by an anomalous region of low and diffuse reflectivity on stacked 2D reflection seismic data. A caldera-style volcanism was interpreted to form the complex with a strong explosive volcanism occurring at the end of the magma emplacement, likely somewhere in the bay where the magnetic ring-structure is observed (Figure 2b).

As part of an interdisciplinary geophysical study involving reflection seismics (Andersson et al., 2013), anisotropy of magnetic susceptibility (Andersson et al., 2016) and potential field methods (this study), new surface gravity and magnetic data were collected to provide information about the deeper interior of the complex and with the aim to test if a shallow magma-chamber can be verified independently by 3D modelling of potential field data over the complex. We propose that by estimating the thickness of the intrusion it is possible to indirectly infer the location of the magma chamber. To the best of our knowledge, the current study and recent studies conducted over the Alnö complex are the most detailed geophysical investigations conducted on any carbonatite complex. This illustrates the potential of an integrated geological, petrophysical and geophysical approach to better understand the internal architecture of such intrusions. The Alnö intrusion on the main island and the inferred volcanic activity in the bay would put Alnö among the few unique geological sites where intrusive and extrusive activities have been recorded at the same locality (cf. Woolley and Church, 2005).

Significant physical property contrasts (e.g., density or susceptibility) must exist between adjacent lithologies in order to delineate them using gravity and magnetic modelling methods. These criteria, as illustrated later in this paper, exist for the Alnö rock types justifying the application of high-resolution modelling to investigate the various lithological entities forming the complex. Successful case studies (cf. Oldenburg et al., 1997; Dutra and Marangoni, 2009) exist, which show the inversion of potential field data (e.g., gravity and magnetic) in many different geological settings. Inversion can also be conducted in conjunction with reflection seismic data in order to reduce the ambiguity when interpreting the results (e.g., Roy and Clowes, 2000; Malehmir et al., 2009; Hedin et al., 2013). Although Andersson et al. (2013) used 2.5D forward modelling of the gravity 
Solid Earth Discuss., doi:10.5194/se-2017-3, 2017

Manuscript under review for journal Solid Earth

Published: 23 January 2017

(c) Author(s) 2017. CC-BY 3.0 License.

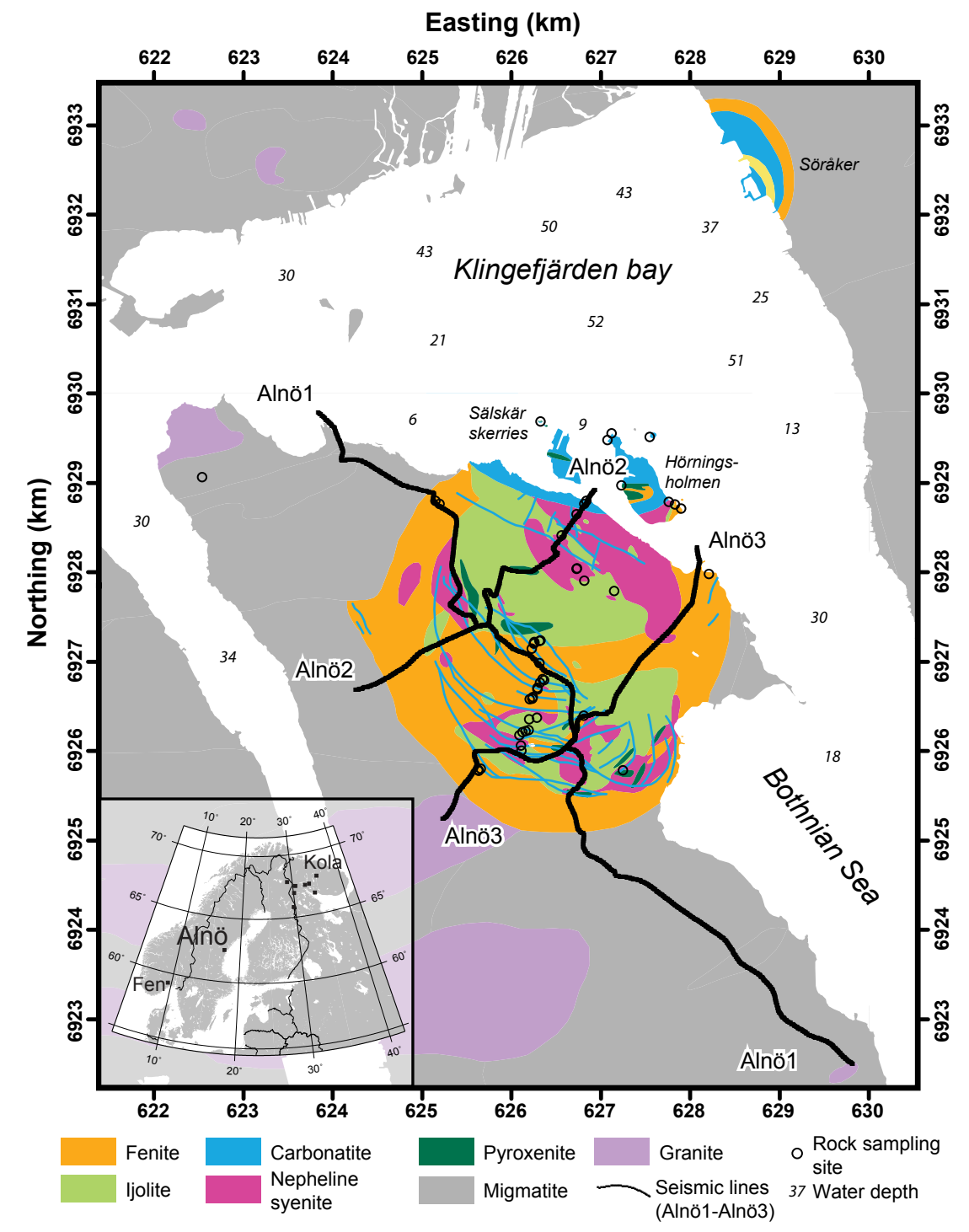

Figure 1. Geological map of the Alnö alkaline and carbonatite ring-complex, central Sweden. Samples for petrophysical measurements were taken from representative rock types in the intrusion area. Black lines show available reflection seismic profiles (Alnö1, 2, and 3) from the study area (Andersson et al., 2013). The inset map of northern Europe shows the location of the Alnö complex, the coeval Fen complex in southern Norway and the swarm of alkaline and carbonatite intrusions in northern Finland and northwestern Russia. The geological map is kindly provided by the Geological Survey of Sweden. The coordinate system is SWEREF99 TM (UTM zone 33N).

data from the study area alongside the reflection seismic profiles to aid in the interpretation, it is clear that the complex shape of the lithological units and their 3D geometry, both at the surface and most likely at depth, justify a full 3D modelling. Therefore, 
Solid Earth Discuss., doi:10.5194/se-2017-3, 2017

Manuscript under review for journal Solid Earth

Published: 23 January 2017

(c) Author(s) 2017. CC-BY 3.0 License.
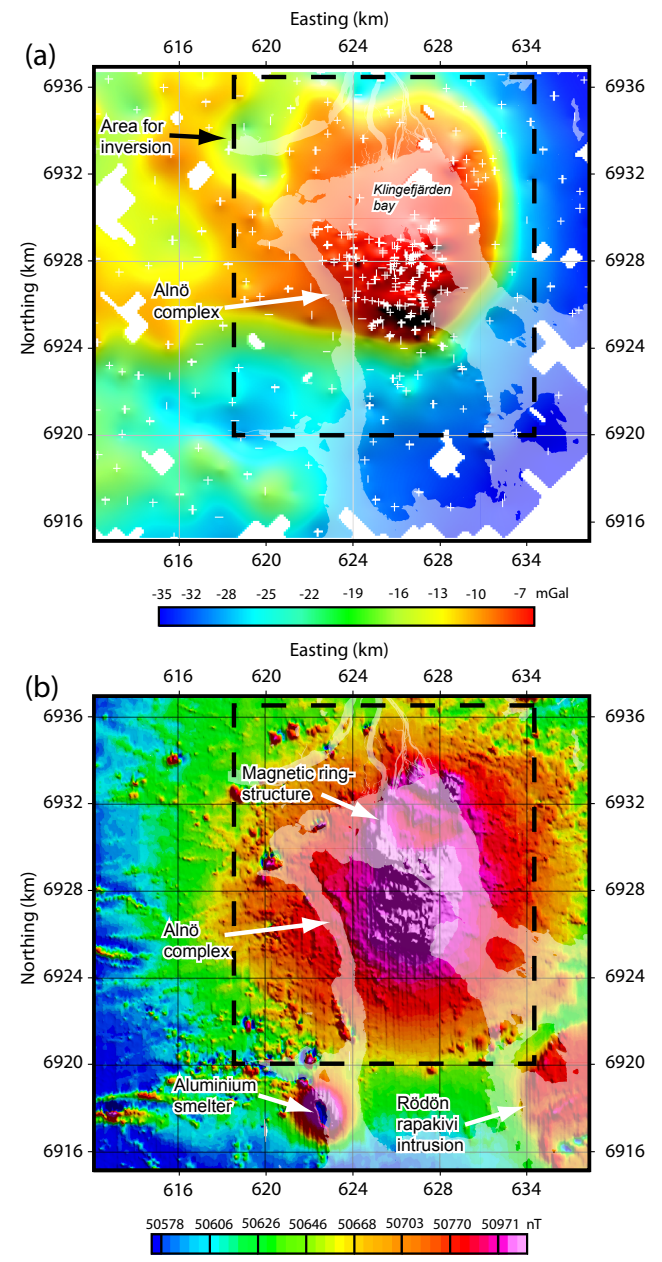

Figure 2. Gravity data. (a) Bouguer anomaly map of the Alnö area. "Plus" signs indicate the locations of the gravity stations. The gravity stations are about $100 \mathrm{~m}$ apart inside and about $1 \mathrm{~km}$ apart outside the intrusion area. (b) Aeromagnetic map of the area, the flight lines run north-south with $200 \mathrm{~m}$ distance between profiles, at a nominal flight-height of $60 \mathrm{~m}$. The magnetic anomaly in the south-eastern corner of the map is related to an older rapakivi granite intrusion outcropping at Rödön Island. A semi-circular anomaly with about $2 \mathrm{~km}$ extent (low-magnetic inside high-magnetic area). The anomaly in the southern part of the map is related to an aluminium smelter. In both maps water surfaces are indicated with pale colour. The rectangle with a dashed line shows the area of interest, the data for inversion were extracted from this area.

the 3D modelling of gravity and magnetic data from Alnö is the major focus of this study with the main objectives of (1) estimating the depth extent of the intrusion in the Alnö Island in order to independently verify the interpretation of the shallow fossil magma chamber, (2) studying the petrophysical properties of different geological units on the island and using them as constraints in the inversion and interpretation, and (3) providing information about the potential link between the intrusion 
Solid Earth Discuss., doi:10.5194/se-2017-3, 2017

Manuscript under review for journal Solid Earth

Published: 23 January 2017

(c) Author(s) 2017. CC-BY 3.0 License.

and the magnetic ring-structure in the bay, which can be an important piece of the puzzle of the emplacement of the complex. Samples from representative rock types were collected and their petrophysical properties measured; in this study we present density, magnetic susceptibility and natural magnetic remanence (NRM). Gravity and magnetic data were inverted with the help of a priori information obtained from the petrophysical measurements. We show how the modelling results suggest two separate regions within the intrusion that are associated with gravity and magnetic highs. They are likely connected at depths at 800-1000 m below the surface, implying a common source for the rocks observed in these two regions. The modelling suggests that a more than $3 \mathrm{~km}$ wide ring-shaped magnetic anomaly observed adjacent to the main intrusion, in the Klingefjärden bay, is caused by a bowl-shaped region of highly magnetic material. The centre of the body is host to a region of materials with a low magnetic susceptibility that extend down to about $2 \mathrm{~km}$ depth. The highly magnetic floor of the "bowl" may be connected with the onshore intrusion at this depth.

\section{Geological background and earlier studies}

\subsection{Geological setting}

The Alnö carbonatite complex (Figure 1) was emplaced into Palaeoproterozoic migmatitic country rock at 584 \pm 7 Ma (Meert et al., 2007). Carbonatites with variable grain sizes and compositions occur as dykes and sheet intrusions (Figure 3a, b) (von Eckermann, 1948; Kresten, 1979, 1990; Morogan and Lindblom, 1995). Carbonatites are igneous rocks that contain more than 50 volume percent of calcite or other carbonate minerals (Le Maitre et al., 2002). The Alnö complex also contains a wide variety of alkaline silicate igneous rocks (e.g., nepheline syenite and ijolite), which are rich in feldspathoid minerals (e.g., nepheline) but lack quartz (Vuorinen, 2005). Pyroxenite occurs as lenses and small intrusions (Figure 3a). Alnöite, a mafic alkaline silicate rock that belongs to the kimberlite family and is melilite-rich, occurs as dykes and diatremes in the Alnö complex and in the surrounding country rock (von Eckermann, 1948). However, they are to small to be indicated on the geological map. The intrusion is surrounded by fenite, which is country rock that has undergone metasomatic alteration by $\mathrm{CO}_{2}$-rich solutions from the intruding carbonatite and alkaline silicate rocks (Morogan and Woolley, 1988; Morogan, 1989; Skelton et al., 2007). The degree of alteration varies with distance from the intrusion, from nearly unaltered approximately $500 \mathrm{~m}$ away to a strongly fenitised variety with no free quartz remaining close to the intrusion (Morogan and Woolley, 1988; Kresten, 1990). The fluid-rock interaction typically adds $\mathrm{Na}_{2} \mathrm{O}, \mathrm{K}_{2} \mathrm{O}, \mathrm{CaO}, \mathrm{MgO}$ and $\mathrm{FeO}$ and reduces $\mathrm{SiO}_{2}$ content $(\mathrm{Kresten}$ and Morogan, 1986; Vuorinen, 2005).

The subsurface geological structures in the complex were initially inferred from surface geological mapping of dip and dip direction of the alkaline silicate rocks and the carbonatite sheet intrusions (von Eckermann, 1948; Kresten, 1980, 1990). A dome-shaped magma chamber with the roof at $\sim 1.5 \mathrm{~km}$ below the current land surface was suggested to have supplied steeply dipping radial dykes and shallow to moderately dipping carbonatite cone-sheets (Kresten, 1980, 1990). The "Sälskär breccia" has been described from boulders found close to the Sälskär skerries (Figure 3c, d); they contain fragments of carbonatites and melilitic lapilli in a carbonatite matrix (Kresten, 1990). The boulders are assumed to be more or less in situ although no outcrop with breccia are found (Kresten, 1990). The breccia is interpreted to be the product of explosive carbonatitic volcanism 
Solid Earth Discuss., doi:10.5194/se-2017-3, 2017

Manuscript under review for journal Solid Earth

Published: 23 January 2017

(c) Author(s) 2017. CC-BY 3.0 License.
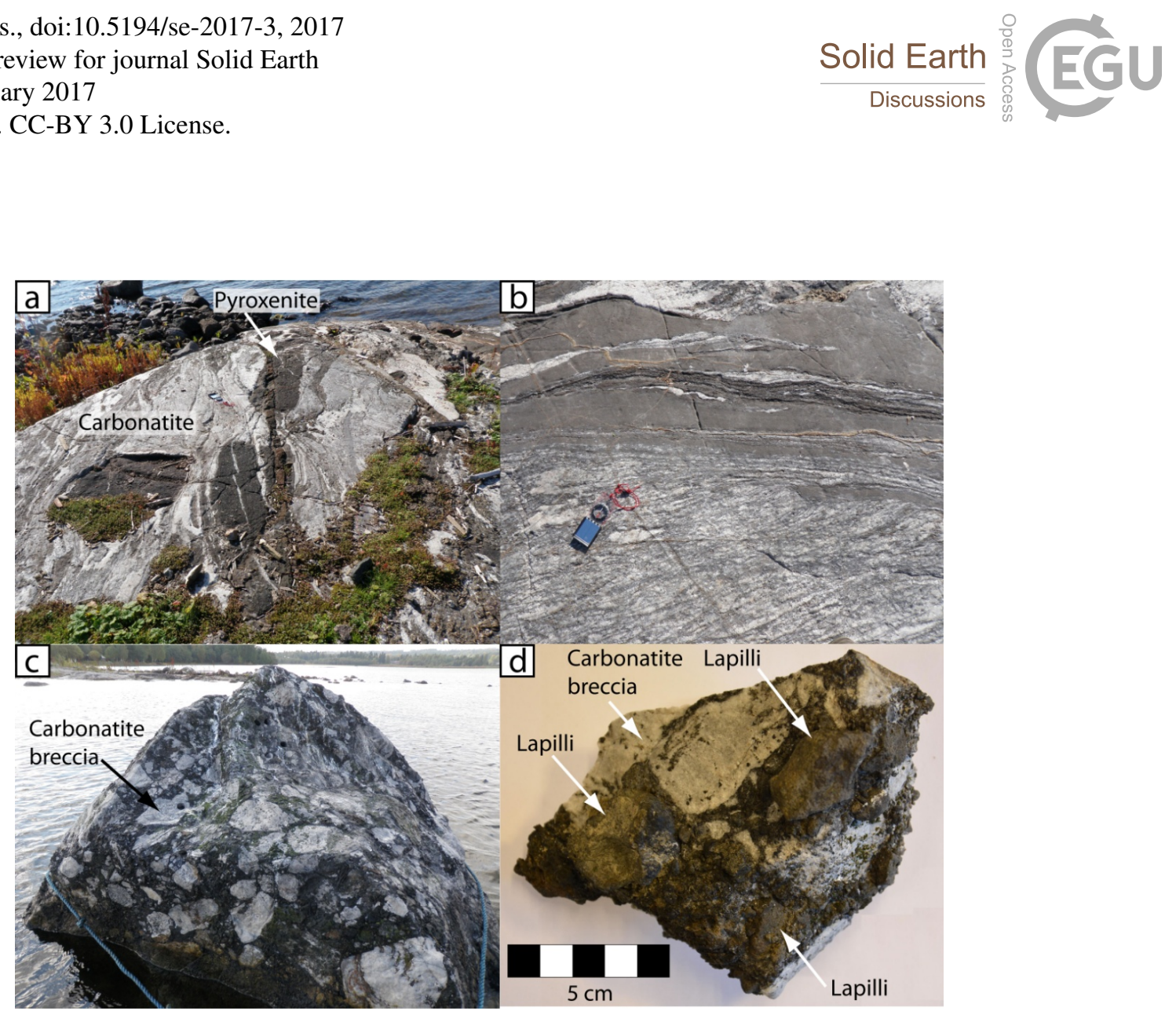

Figure 3. (a) Coarse-grained carbonatite in outcrop. A more competent pyroxenite dyke shows boudinage structure. A younger fine-grained carbonatite dyke (brown) cross-cuts the boudinage. (b) A fine-grained (dark) carbonatite dyke cross-cuts a coarse-grained carbonatite dyke. (c) A boulder of breccia in the water between the western and eastern Sälskär skerries. The boulder contains fragments of carbonatites and melilitic lapilli in a carbonatite matrix. The borehole marks are $2.5 \mathrm{~cm}$ in diameter. (d) A sample from the boulder in (c), showing carbonatite fragments and lapillis.

(Kresten, 1990; Andersson et al., 2013). About $500 \mathrm{~m}$ surface erosion is estimated to have occurred in the study area (Kresten, 1990) since the time of intrusion.

Small-scale petrophysical data are available from the Alnö Island. For example, Piper (1981) and Meert et al. (2007) focussed on palaeomagnetic properties and natural remanent magnetisation measured on oriented drillcores; emphasis was given to the

5 emplacement time and the palaeogeographic position of Baltica during the Neoproterozoic era. Malehmir et al. (2013) and Andersson et al. (2013) published measurements of ultrasonic velocities and densities of a collection of samples from a number of localities in Alnö.

\subsection{Reflection seismics and anisotropy of magnetic susceptibility}

The seismic study by Andersson et al. (2013) focussed on the data acquisition, processing and interpretation of three highresolution reflection seismic profiles crossing the Alnö complex (Figure 1); one about $9 \mathrm{~km}$ long (Alnö1) and two profiles that were about $4 \mathrm{~km}$ long each (Alnö2 and Alnö3). The acquisition was performed with a nominal source and receiver spacing of 
Solid Earth Discuss., doi:10.5194/se-2017-3, 2017

Manuscript under review for journal Solid Earth

Published: 23 January 2017

(c) Author(s) 2017. CC-BY 3.0 License.

$10 \mathrm{~m}$. A VIBSIST ${ }^{\mathrm{TM}}$ hammer was used to generate the seismic signal (Andersson et al., 2013) with 3-5 sweeps at each source location. A diffuse reflection pattern in the centre of the longest profile (Alnö1) was interpreted to represent a shattered and sunken central caldera block that extends down to about $3 \mathrm{~km}$ below the present day land surface. Below the caldera block a seismically transparent zone was suggested to relate to an up to $1 \mathrm{~km}$ thick solidified saucer-shaped magma chamber; today

5 just a pluton. The seismically transparent zone suggests a more homogenous rock, likely a mixture of carbonatite and alkaline rock, which differ from the rocks above the magma chamber. The maximum depth continuation of the complex (including the pluton) was estimated to about $4 \mathrm{~km}$ below the surface using 2.5D forward gravity modelling (Andersson et al., 2013). An initial up-doming indicated from the seismic reflectivity pattern that begins with flat lying reflectors far from the intrusion at about $4 \mathrm{~km}$ depth, which become gradually more steeply dipping reflectors closer to the surface and the intrusion, was argued to favour the location of the fossil magma chamber.

A recently conducted study focussing on the anisotropy of magnetic susceptibility (AMS) of carbonatite dykes revealed a pattern of the magnetic fabric that follows the orientation of the dykes (Andersson et al., 2016). AMS results are commonly presented as susceptibility ellipsoids and it was found that most of the AMS measurements showed oblate ellipsoid shape. The dominance of oblate shape was interpreted to represent re-orientation or deformation of magnetite grains due to dyke closure at a late stage of magma transport, probably due to pressure drop in the dyke (Andersson et al., 2016).

\section{Data and methods}

\subsection{Petrophysical measurements}

The above mentioned AMS study was the main purpose to collect drill cores, but they became available to this study because AMS measurements are conducted with a weak applied magnetic field which is non-invasive. The sample set constitutes a collection of block samples and drill cores $(25.4 \mathrm{~mm}$ in diameter and up to $\sim 10 \mathrm{~cm}$ long) from the main rock types available in outcrops in the Alnö Island and the small islands north of it (see Figure 1 for locations). The core samples were drilled with a handheld gasoline-powered drill. All drill cores and some of the block samples were oriented with a sun compass. The samples were measured for their density and bulk susceptibilities $\left(k_{m}\right)$; some samples were also measured for their natural remanent magnetisation (NMR). The density measurements presented here are an extension of the dataset that was presented in Andersson et al. (2013). In total 207 samples were measured for density, more than 250 samples for bulk magnetic susceptibility and 40 samples for remanent magnetisation. Elastic wave velocities at ultrasonic frequency were also measured earlier but not shown nor discussed here (see Andersson et al., 2013; Malehmir et al., 2013). Table 1 shows a summary of the physical property measurements for different rock types from the Alnö complex, whereas the data is presented in the supplementary information.

\subsubsection{Density and magnetic susceptibility measurements}

30 Prior to the preparation of sub-samples (21 mm long) suitable for AMS measurements (Andersson et al., 2016), the core samples were measured for their densities. The weight of each sample was measured in air and subsequently in water allowing 
Solid Earth Discuss., doi:10.5194/se-2017-3, 2017

Manuscript under review for journal Solid Earth

Published: 23 January 2017

(c) Author(s) 2017. CC-BY 3.0 License.

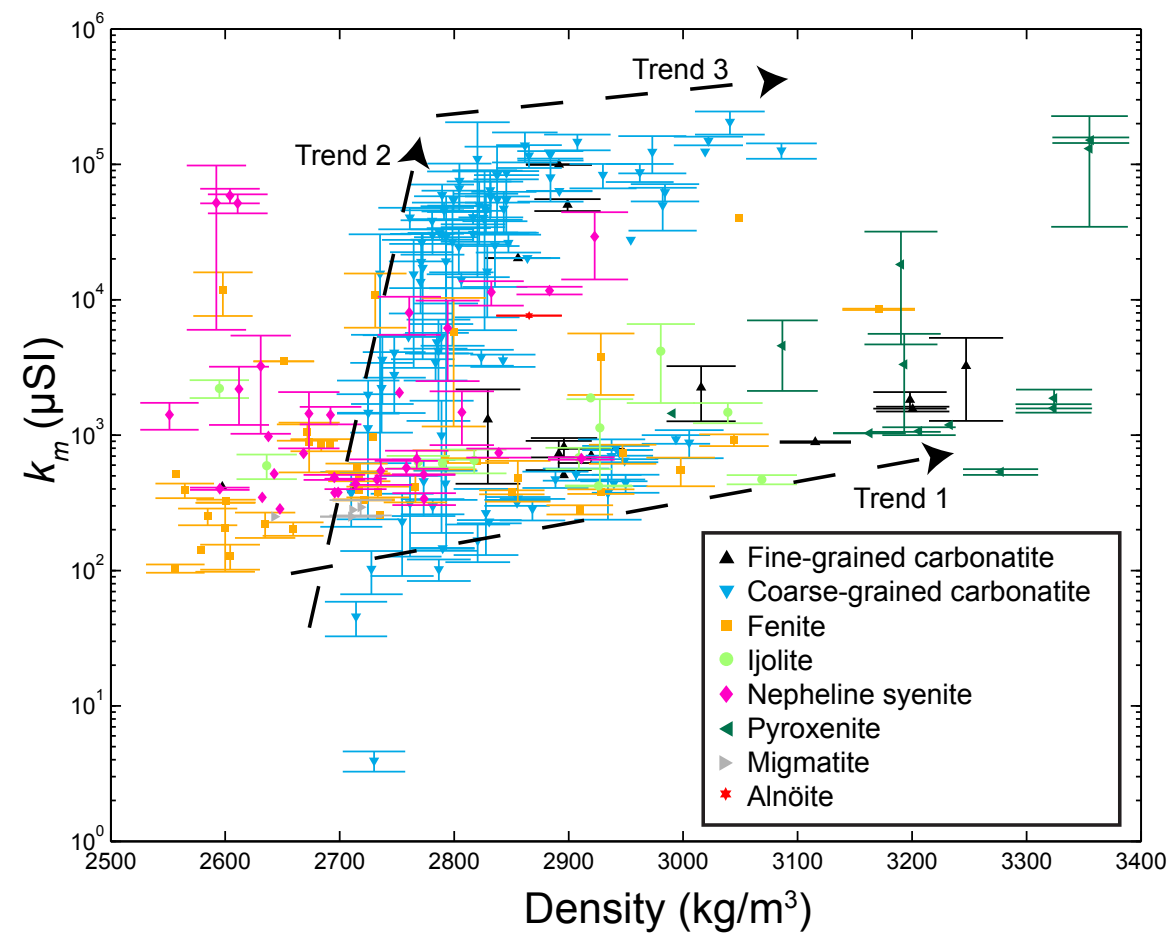

Figure 4. Density versus magnetic susceptibility. Scatter plot, with vertical error bars (one standard deviation), showing the density versus mean bulk susceptibility $\left(k_{m}\right)$ data measured in this study. The density of the samples ( 1 inch drill cores) were first measured and then subsequently cut into $21 \mathrm{~mm}$ long sub-samples and measured for $k_{m}$. Three trends are evident, which are discussed in the text. A total of 207 measurements are plotted.

the density to be calculated using Archimedes' principle. The bulk susceptibilities of the sub-samples were measured with an Agico KLY-2 Kappabridge ${ }^{\mathrm{TM}}$ at Lund University. Some of the samples were measured with an AC Bridge at the Geological Survey of Sweden (SGU). The magnetic field used was $48 \mathrm{~A} / \mathrm{m}$ inside the coil system for the AC Bridge (Puranen et al., 1993); this value was later used to calculate the isolines for Königsberger ratio shown in this paper. Figure 4 presents density 5 versus bulk magnetic susceptibility measurements for all the samples and sub-samples. A focus was given to the carbonatites (fine- and coarse-grained), as they were the most interesting rock type in the complex for the AMS study. This is reflected in the measurements. Most samples show relatively high magnetic susceptibility, especially some of the carbonatites, nepheline syenites and pyroxenites. Pyroxenite, ijolite and nepheline syenite show much higher density than the wall rocks (migmatite and fenite). 
Solid Earth Discuss., doi:10.5194/se-2017-3, 2017

Manuscript under review for journal Solid Earth

Published: 23 January 2017

(c) Author(s) 2017. CC-BY 3.0 License.

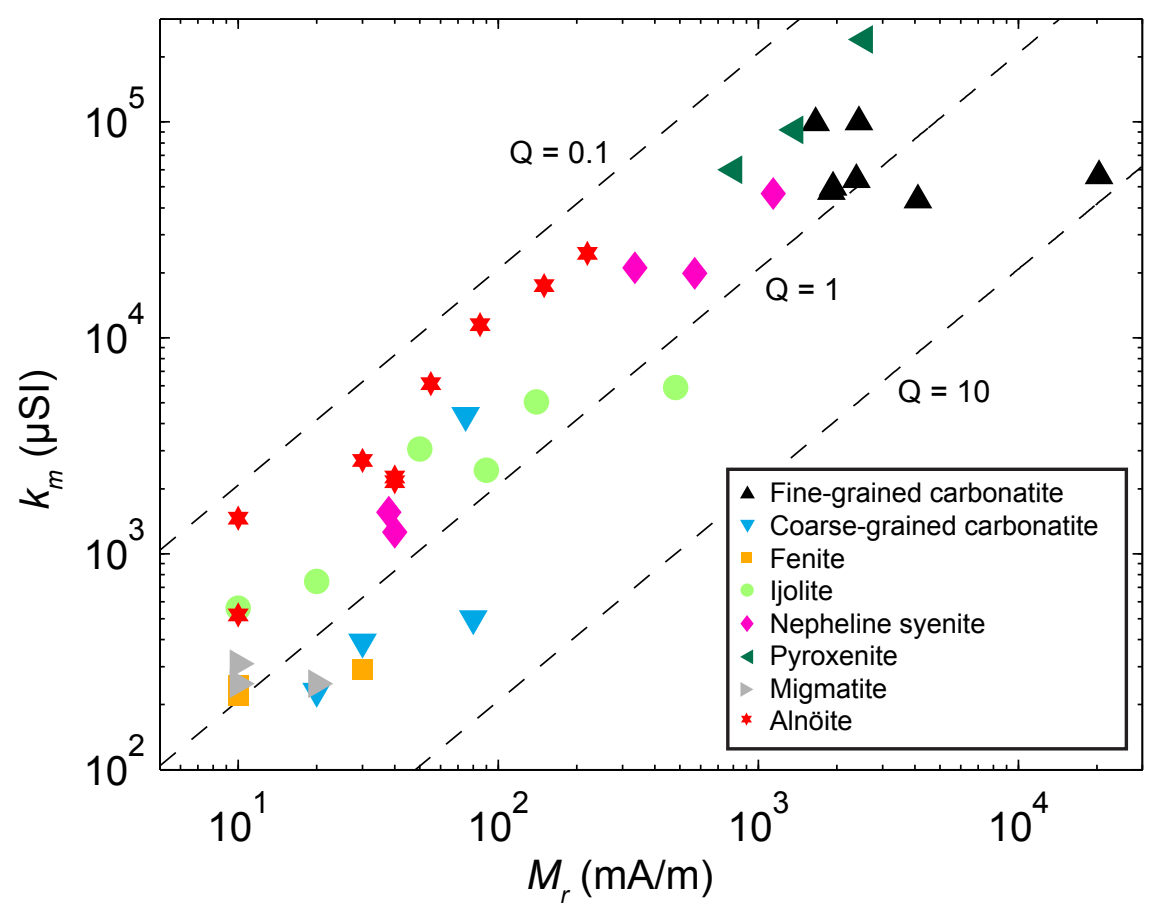

Figure 5. Remanent magnetisation $\left(M_{r}\right)$ versus bulk susceptibility $\left(k_{m}\right)$. Isolines indicate Königsberger ratios $(Q)$ of $0.1,1$, and 10 . A few rock samples show high remanent magnetisation $(Q \geq 1)$; remanent magnetisation dominates over induced magnetisation for these samples. A total of 40 measurements are plotted.

\subsubsection{Natural remanent magnetisation}

Natural remanent magnetisation (NRM) was measured with a remanence meter (Bartington MAG-03MLSTM fluxgate magnetometer) at SGU on a selection of block samples. The remanence meter has a lower limit of detection of $10 \mathrm{~mA} / \mathrm{m}$, with an error of $\pm 5 \mathrm{~mA} / \mathrm{m}$. Samples with relatively weak remanence therefore have considerable uncertainty (50\% for a sample with 5 a remanence of $10 \mathrm{~mA} / \mathrm{m}$ ), but in the case of higher remanence the error is usually negligible. Samples with remanence lower than $10 \mathrm{~mA} / \mathrm{m}$ were excluded from the study. Figure 5 presents the NRM measurements as a function of bulk susceptibility suggesting that most of the samples have relatively low remanent magnetisation, essentially with a Königsberger ratio of less than 1 .

\subsection{Gravity and magnetic data}

10 Ground gravity and magnetic data have been collected since 2010 in conjunction with the reflection seismic studies (Andersson et al., 2013) and in follow-up field campaigns to provide a much wider area and better coverage for the current study. While 
Solid Earth Discuss., doi:10.5194/se-2017-3, 2017

Manuscript under review for journal Solid Earth

Published: 23 January 2017

(c) Author(s) 2017. CC-BY 3.0 License.

ground magnetic data were also measured, they are not used in the modelling due to their limited areal coverage. Instead, high-resolution total-field aeromagnetic data were used for this purpose.

\subsubsection{Acquisition and preparation of gravity data}

More than 400 gravity data points were acquired during the years 2010 to 2012 using a LacosteRomberg ${ }^{\mathrm{TM}}$ model G gravimeter.

5 Most points were measured on land, but a few on the sea-ice (shallow-water) north of the island during winter 2011. The same base-station and instrument were used for all the field campaigns. Standard processing of the data was applied (tidal correction, latitude correction, terrain correction) and the Bouguer anomaly was calculated with the assumption of a background density of $2670 \mathrm{~kg} / \mathrm{m}^{3}$. These measurements were shifted and merged with additional gravity data points provided by SGU (Figure 2a). In total 610 gravity data points were used, covering the main complex and the surroundings. We estimate about $0.1 \mathrm{mGal}$ data error in the preparation of the data until complete Bouguer response; hence we used an RMS misfit of $0.2 \mathrm{mGal}$ during the inversion (Malehmir et al., 2016).

The Bouguer gravity anomaly is not only about $20 \mathrm{mGal}$ higher over the complex than for the background rocks (migmatites), it also shows a strong horizontal gradient towards the centre of the complex. This is by far the most noticeable gravity gradient anomaly observed in Sweden. The gravity anomaly clearly illustrates the extent of the complex, especially on land and in the southern and eastern parts of the study area where it shows the strongest gradient (Figure 2a).

\subsubsection{Preparation of magnetic data}

The aeromagnetic data (Figure $2 \mathrm{~b}$ ) used in this study were collected using a high-resolution caesium vapour magnetometer. The lines were flown in north-south directions at $60 \mathrm{~m}$ nominal altitude, with $16 \mathrm{~m}$ sampling spacing and $200 \mathrm{~m}$ flight line distance. The aeromagnetic data were delivered with ground clearance information from radar altitude measurements. The ground clearance and elevation data were added together to obtain the correct locations above sea level for the measurements. The dataset was decimated to a grid of $100 \mathrm{~m}$ by $100 \mathrm{~m}$; this provided a dataset containing 18620 data points for the inversion. Error in these types of data is estimated to be on the order of 1-5 nT (after all the necessary corrections).

The aeromagnetic data uniformly cover the complex on land but also over the sea, revealing smaller-scale structures. Similar to the gravity data, magnetic data clearly show the extent of the complex, a magnetic high in the centre of the complex on the main island and in addition a ring-shaped magnetic anomaly at the margin of the complex in the bay. Two smaller but noticeable magnetic anomalies are also observed in the southern part of the study area, one generated from a major industrial complex (an aluminium smelter), and one in the south-eastern corner from the Rödön rapakivi granite intrusion, which has been dated to 1500 Ma (Welin, 1994; Lundqvist et al., 1990; Andersson, 1997). The magnetic anomaly over the Alnö complex is on the order of $2000 \mathrm{nT}$ (Figure 2b), which makes the complex standing out from the surrounding migmatitic rocks. 
Solid Earth Discuss., doi:10.5194/se-2017-3, 2017

Manuscript under review for journal Solid Earth

Published: 23 January 2017

(c) Author(s) 2017. CC-BY 3.0 License.

\subsubsection{Regional-residual removals}

Most gravity and magnetic modelling methods are formulated based on the assumption of no background effects on the data, a so-called regional-residual separation is required to fulfil this criteria. This is still a topic of research and there are many ways to separate the regional fields (e.g., Li and Oldenburg, 1998b; Nabighian et al., 2005). After testing a few simple methods, we decided to use a first-order polynomial surface (Figure 6a) fitted to the observed gravity data to represent the regional gravity field. Residual gravity (Figure 6b) was then used for the modelling. The gravity anomaly is better isolated in Figure $6 \mathrm{~b}$ than in Figure 2a. A second-order polynomial field was also tested but was not optimal as it removed the long wavelength components of the target anomaly. The main Alnö gravity anomaly is successfully separated from the background field after removing the regional trend, this implies that a first-order regional field is suitable for this purpose (Li and Oldenburg, 1998b; Malehmir et al., 2009; Hedin et al., 2013).

According to the IGRF model (NOAA, 2015), at the time of the aeromagnetic data acquisition (1997), the earth magnetic field intensity was $50710 \mathrm{nT}$, inclination $74.4^{\circ}$, and declination $5.4^{\circ}$ in the Alnö area. Given the small size of the study area, a constant IGRF value should be sufficient and reasonable for removing the regional field that is represented by long-wavelength anomalies from deeper structures. We tested the polynomial approach as for the gravity data, however, after inspecting the results we decided to use a constant value that is close to the IGRF value from the site but nearly zeros the magnetic field from the background rocks (i.e., surrounding migmatites).

\subsection{D Gravity and magnetic inversion}

The inversions of gravity and magnetic data were performed using GRAV3D ${ }^{\mathrm{TM}}$ and MAG3D ${ }^{\mathrm{TM}}$, which are based on the methods described by Li and Oldenburg $(1996,1998 \mathrm{a})$. The general workflow followed is presented in Figure 7. An inversion model consists of a mesh with rectangular cells where each cell has its own constant density or susceptibility values. The cell size can vary both laterally and vertically; so increased cell size (padding) can be included on the sides and in depth without a significant increase in computation time. The inversion is initiated with a starting model (homogenous or constrained) and the property of each cell is updated through a conjugate-gradient inversion method until the forward response of the whole mesh matches the observed data within a predefined error value (data error or slightly higher as used in this case). A depth weighting function is used to the sensitivity matrix values to increase the contribution of the deeper cells. Without the depth weighting function the density/susceptibility values would be unrealistic, generating a highly variable model in the near surface (Li and Oldenburg, 1998a). A range of lower and upper property bounds (density contrast and susceptibility in this case) can also be used to constrain the model, and if available a reference model (highly constrained-inversion) where the final model should be as close as possible to the reference model (e.g., Hedin et al., 2013). In addition, a general smoothness constraint can also be applied. A drawback of the inversion method is that the model obtained is non-unique and has an increasing ambiguity at depth.

In this study we chose $100 \mathrm{~m}$ by $100 \mathrm{~m}$ cells in the lateral directions. To reduce the edge effects from the inversion (Li and Oldenburg, 1998a), the target area was padded with $2.5 \mathrm{~km}$ of cells on each side (N, E, S, and W), using $100 \mathrm{~m}$ cells, except 
Solid Earth Discuss., doi:10.5194/se-2017-3, 2017

Manuscript under review for journal Solid Earth

Published: 23 January 2017

(c) Author(s) 2017. CC-BY 3.0 License.
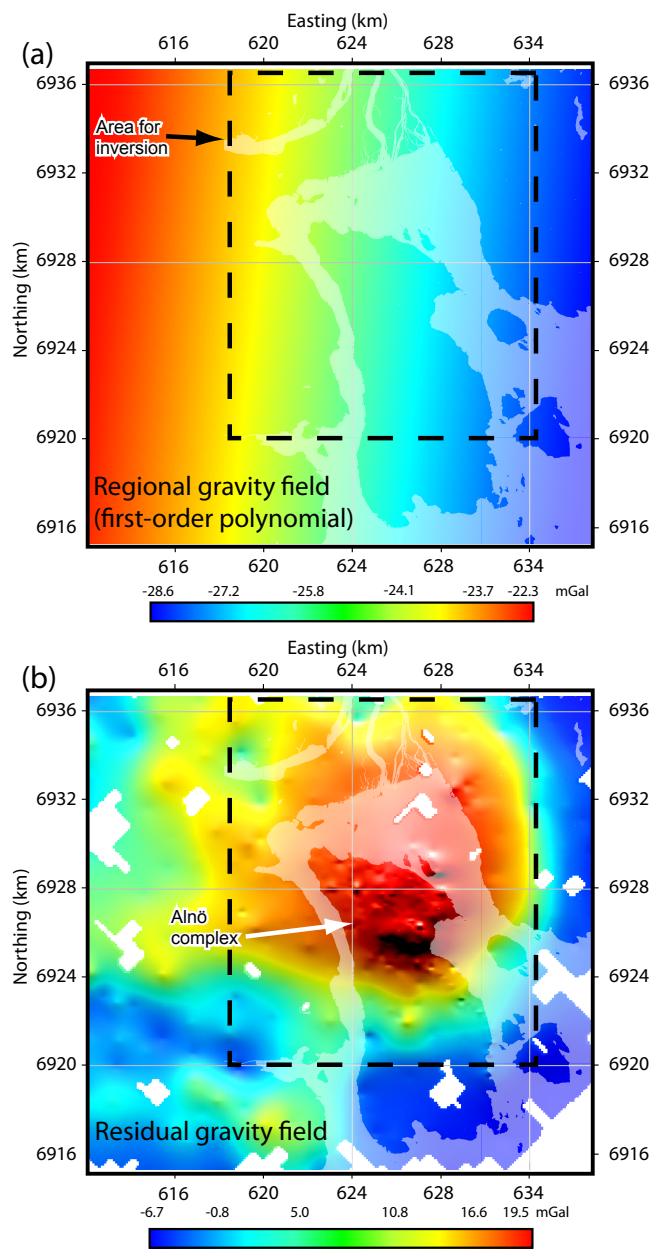

Figure 6. Removal of regional gravity data. (a) Regional gravity field calculated using a first order polynomial from the observed gravity data. (b) The residual of the Bouguer anomaly calculated by subtracting the regional gravity field from the Bouguer anomaly (Figure $2 a$ ).

for the two outermost layers of cells which were $200 \mathrm{~m}$ and $400 \mathrm{~m}$, respectively. Given the spacing between the gravity points (on average $100 \mathrm{~m}$ ), cells smaller than $100 \mathrm{~m}$ were not justified for any part of the model. The vertical dimension of the cells increases with the depth; above sea level the cell thicknesses were $10 \mathrm{~m}$. Below sea level, the cells ranged in thickness from 20 $\mathrm{m}$ at $0 \mathrm{~m}$ to $2770 \mathrm{~m}$ at $8350 \mathrm{~m}$ depth (Table 2). The inversion uses the real topography of the surface obtained from the national 5 topographic grid $(50 \mathrm{~m} \times 50 \mathrm{~m})$. Both GRAV3D ${ }^{\mathrm{TM}}$ and MAG3D ${ }^{\mathrm{TM}}$ software can handle topography by disregarding all cells in the meshes that occur above the topographic surface. In order to provide comparative data, we decided to use identical meshes and model size for the inversion of gravity and magnetic data. Nevertheless, the inversion was done separately. 
Solid Earth Discuss., doi:10.5194/se-2017-3, 2017

Manuscript under review for journal Solid Earth

Published: 23 January 2017

(c) Author(s) 2017. CC-BY 3.0 License.

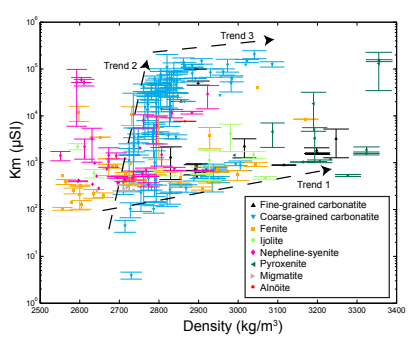

Upper and lower density bounds

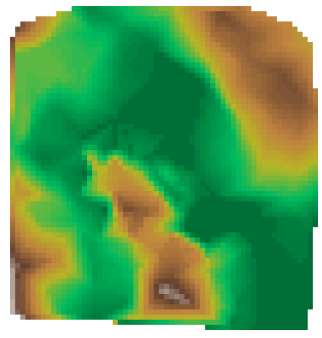

Topographic information

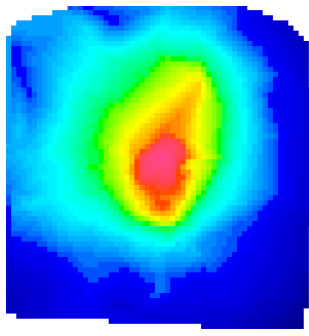

Observed gravity data

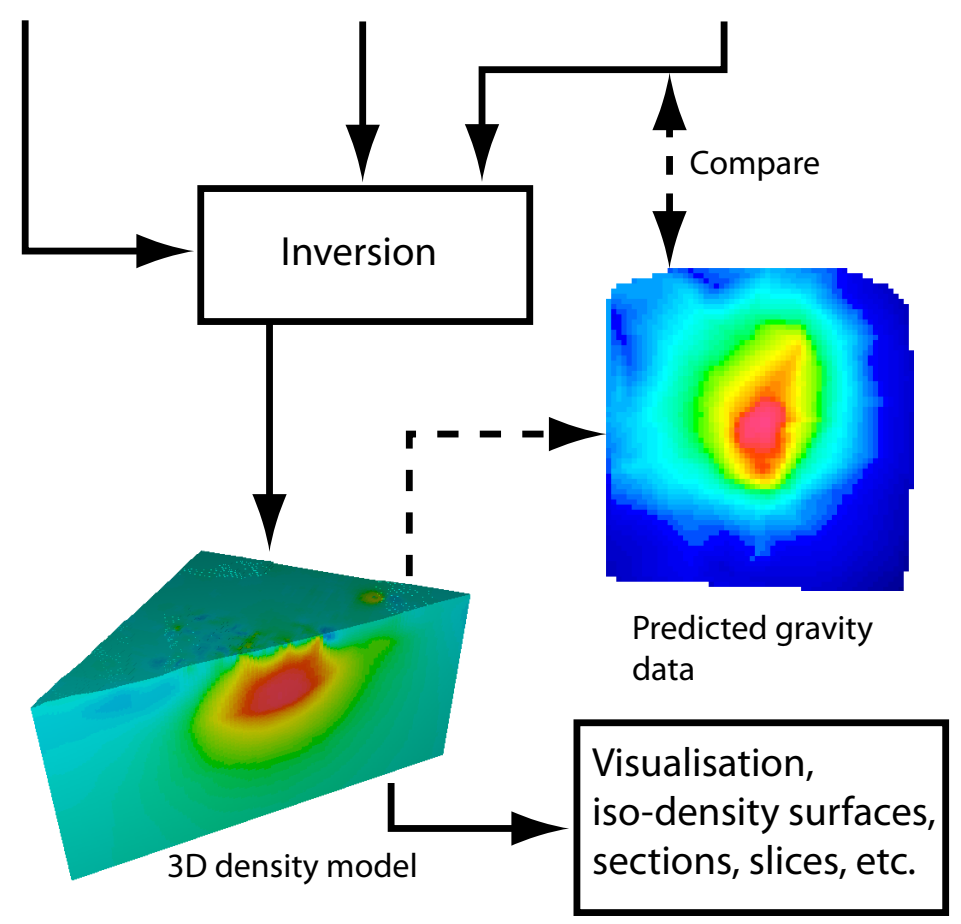

Figure 7. Workflow used for the 3D inversion of the gravity and aeromagnetic data (see also Meixner and Lane, 2005)

\subsubsection{Gravity inversion}

Out of the 610 gravity data points, 27 of them were discarded since they were located beneath the modelled earth surface due to a mismatch between the accurate gravity elevation measurements and regional topography data. A value of $0.2 \mathrm{mGal}$ was assigned to the standard deviation of data points as well as the target misfit error, which is about $1 \%$ of the maximum anomaly

5 in the study area. The inversion in GRAV3D ${ }^{\mathrm{TM}}$ uses relative density values, not the absolute density values. Therefore it allows for both positive and negative densities that should be considered as deviations from an average density value for the target 
Solid Earth Discuss., doi:10.5194/se-2017-3, 2017

Manuscript under review for journal Solid Earth

Published: 23 January 2017

(c) Author(s) 2017. CC-BY 3.0 License.

area. The starting model was set to $0 \mathrm{~kg} / \mathrm{m}^{3}$ for all the cells in the mesh, roughly corresponding to a density of $2670 \mathrm{~kg} / \mathrm{m}^{3}$ for the background rocks (Figure 4). We used a lower and upper density bound of 1000 and $1000 \mathrm{~kg} / \mathrm{m}^{3}$ (1760 to $3760 \mathrm{~kg} / \mathrm{m}^{3}$ ) to constrain the gravity inversion, however, in the final inversion models no values exceeded -251 and $+432 \mathrm{~kg} / \mathrm{m}^{3}$ (2419 to 3102 $\mathrm{kg} / \mathrm{m}^{3}$ ). The majority of the cells in the final inversion models have values in the interval -100 to $+380 \mathrm{~kg} / \mathrm{m}^{3}$ (2570 to 3050

$5 \mathrm{~kg} / \mathrm{m}^{3}$ ) as shown later in the paper. This is reasonable given the density measurements shown in Figure 4 . Several inversion tests were performed with tighter bounds on the density, however these did not converge or they resulted in geologically unrealistic models. The gravity inversion model shown in this paper is one of the models obtained, which we feel is both geologically reasonable and stable (i.e., similar to a number of models achieved using varying starting parameters). Both the observed data and the data forward modelled from the inversion result, as well as their misfit are shown in Figure 8.

\subsubsection{Magnetic inversion}

The inversion of magnetic data with MAG3D ${ }^{\mathrm{TM}}$ uses the total magnetic susceptibility $\left(k_{m}\right)$ (Li and Oldenburg, 1996). The inversion code allows negative susceptibilities unless it is constrained not to do so by setting the lower bound to zero (Li and Oldenburg, 1996). Remanent magnetisation can generally have a great influence on the magnetic data and models (Tarling and Hrouda, 1993), however, it is difficult to obtain a good estimation of the size and the direction of the remanence for the whole rock volume that is inverted for. It is assumed that the magnetic anomaly is produced by induced magnetisation and that there is no remanent magnetisation or demagnetisation effect ( $\mathrm{Li}$ and Oldenburg, 1996). This is unlikely to be a significant issue in our case since the remanent magnetisation is relatively weak in the samples $(Q<1$, see Figure 5). A uniform zero-susceptibility was used as the starting model. To partly constrain the inversion, we used a lower and upper bounds of zero and 0.1055 SI units, respectively. The upper bound choice was motivated from the petrophysical measurements (Figure 4). The inversion was run iteratively with updated susceptibility values until the forward modelling reproduced the observed data within an error misfit of $30 \mathrm{nT}$. Similar to the gravity inversion, several inversion tests were carried out and the model shown in this paper represents only one of those that can be explained by the available data and our understanding of the geology. Thus, it is not unique and other scenarios can explain the observed data. The predicted magnetic data show that the inversion model has some problems to reproduce the large peaks in the magnetic field over the southern part of the intrusion and also parts of the ring-shaped anomaly measured over the bay (Figure 9c). We think this is due to the smoothing nature of the inversion and likely is a result of regularisation and the choice of cell size.

\section{Results}

\subsection{Petrophysical measurements}

For the alkaline rocks (i.e., the fenite, nepheline syenite, pyroxenite, and ijolite), the magnetic susceptibility is mainly controlled by paramagnetic mafic minerals. An increase in density of about $400 \mathrm{~kg} / \mathrm{m}^{3}$ corresponds to an increase in $k_{m}$ from 100 to 1000 $\mu$ SI (Trend 1 in Figure 4). Some of the carbonatite samples follow the same trend, whereas the majority show a strong increase 
Solid Earth Discuss., doi:10.5194/se-2017-3, 2017

Manuscript under review for journal Solid Earth

Published: 23 January 2017

(c) Author(s) 2017. CC-BY 3.0 License.
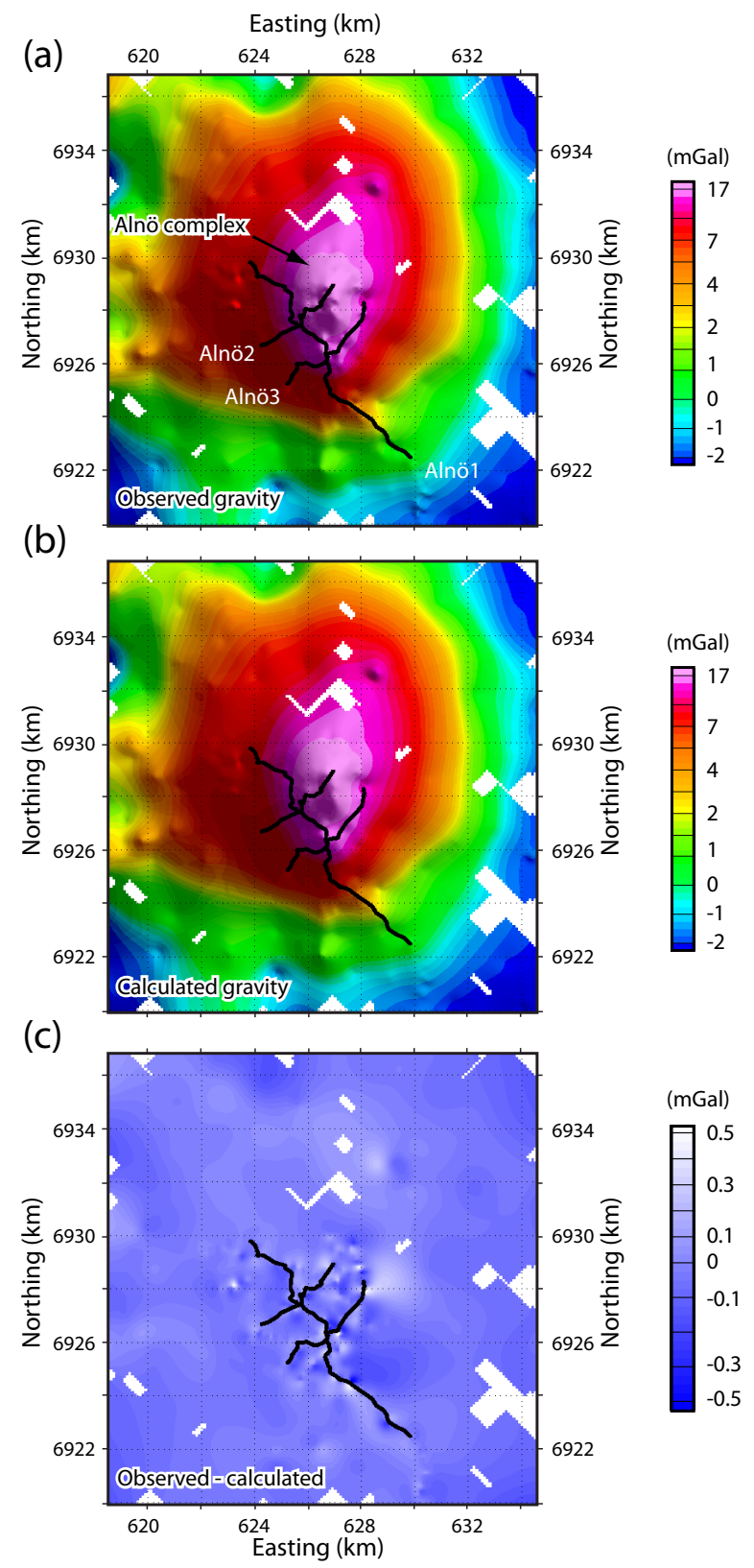

Figure 8. Comparison of observed and calculated gravity data. (a) Observed gravity data, after the removal of the regional field, which was used in the inversion. (b) Calculated response of the final 3D model. (c) Data misfit, predicted data subtracted from the observed data, showing an overall good fit to the data. Note that the higher misfits are located where the gravity stations are densely spaced (i.e., along the seismic lines). This results from the smoothing used in the inversion. 
Solid Earth Discuss., doi:10.5194/se-2017-3, 2017

Manuscript under review for journal Solid Earth

Published: 23 January 2017

(c) Author(s) 2017. CC-BY 3.0 License.
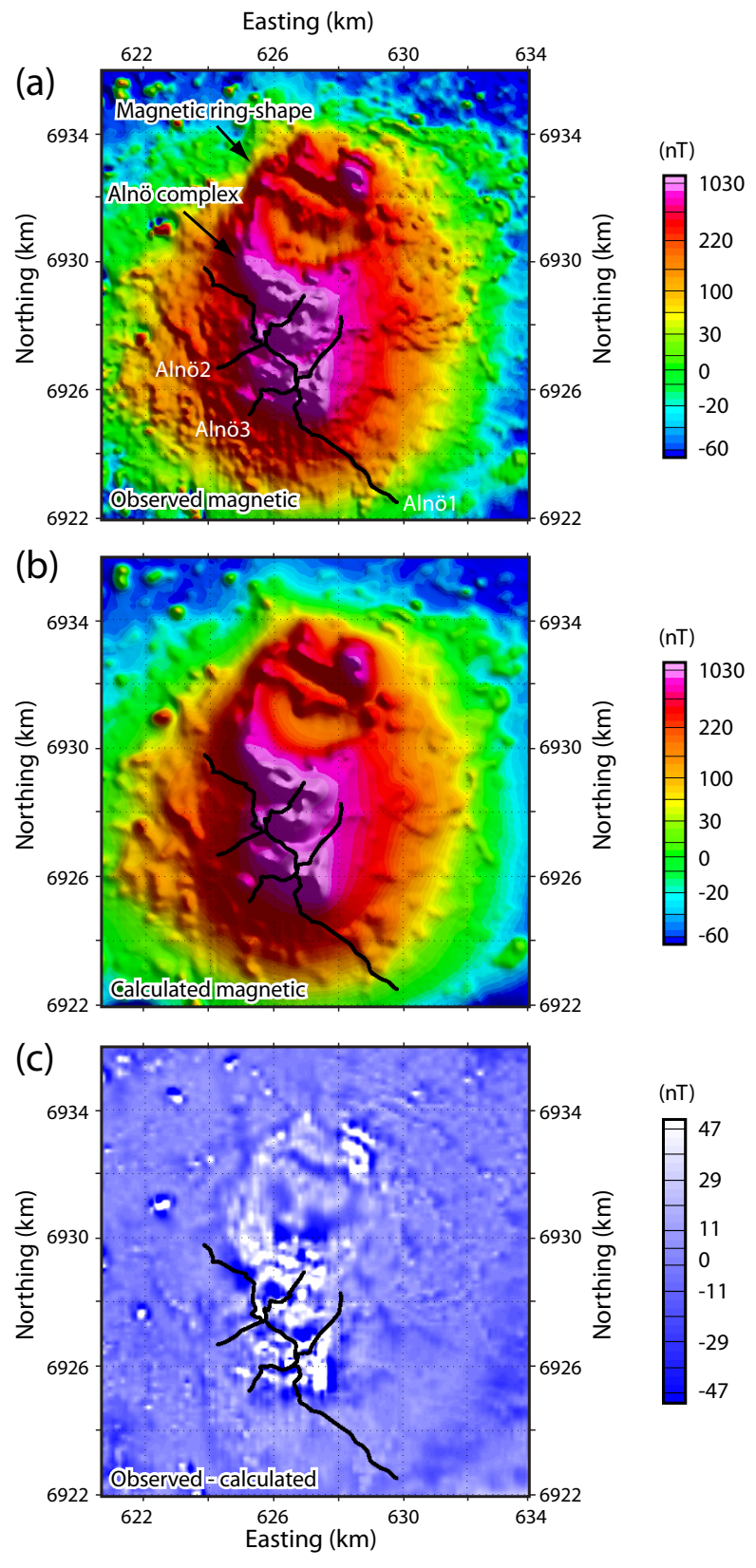

Figure 9. Comparison of observed and calculated magnetic data. (a) Observed magnetic data that was used in the 3D inversion. (b) Calculated response of the final 3D model. (c) Data misfit, which is most pronounced in areas with short wavelength magnetic anomalies.

in susceptibility with only a small increase in the density (Trend 2 in Figure 4). This suggests that a small proportion of ferromagnetic minerals dominate the susceptibility of these carbonatite samples. Finally, some carbonatites follow the third 
Solid Earth Discuss., doi:10.5194/se-2017-3, 2017

Manuscript under review for journal Solid Earth

Published: 23 January 2017

(c) Author(s) 2017. CC-BY 3.0 License.

trend with high bulk susceptibilities but also relatively high densities, which may be an indication that their susceptibility is controlled by both paramagnetic mafic silicates and ferromagnetic minerals (Trend 3 in Figure 4).

Both the direction and intensity of the NRM were measured. For most samples the NRM inclination and declination are sub-parallel to the present Earth's magnetic field (inclination $\sim 74^{\circ} \mathrm{N}$ ), particularly for rocks with strong NRM intensity such

5 as carbonatite, ijolite, nepheline syenite, and pyroxenite (Figure 5). Migmatite and fenite show weak magnetisation $\left(M_{r}<10\right.$ $\mathrm{mA} / \mathrm{m}$ ) thus it was not possible to measure their NRM direction. The relationship between natural remanent magnetisation and bulk susceptibility are shown in Figure 5; the three isolines show values of Königsberger ratio $Q=0.1, Q=1$, and $Q=$ 10, respectively. Most samples plot between the isolines $Q=0.1$ and $Q=1$ indicating that they are dominated by induced magnetisation. Samples with a Königsberger ratio higher than 1 are dominated by remanent magnetisation and contain mostly coarse- and fine-grained carbonatites.

\subsection{Gravity and magnetic modelling}

Both gravity and magnetic inversion models suggest dense $\left(>2850 \mathrm{~g} / \mathrm{cm}^{3}\right)$ and highly magnetically susceptible (>0.05 SI) rocks that extend down to about 3.5-4 km depths. Depth slices through the modelled density and susceptibility volumes are shown in Figure 10. The magnetic model is more reliable and has higher resolution in comparison to the density model in the region of Klingefjärden bay, because there are no gravity data collected in the centre of the bay, only close to land (water depth $<5 \mathrm{~m}$; measured on the sea-ice). However, the gravity high is present on all sides of the Klingefjärden bay as shown in Figure 2a.

In order to compare the results of the independent inversions, a cross-plot of the density versus susceptibility for each cell in the models is shown in Figure 11. It is interesting to observe a similar pattern and amplitude for the modelled properties as those obtained in the laboratory (Figure 4). Trends 2 and 3 in Figure 4 have their counterparts in Figure 11, but Trend 1 is not represented. Although the largest parts of the values in Trend 2 relate to cells in the model that are away from the main anomaly (i.e., background values) and show density contrast close to zero, some of them show increased magnetic susceptibility. This implies that susceptibility has greater control on the properties for this trend than the density.

In order to provide direct comparison between the modelling results and the available reflection seismic data (Andersson et al., 2013), density and susceptibility slices along these profiles were extracted. We use density labels (D1, D2, etc.) and susceptibility labels (S1, S2, etc.) to highlight areas of interest for the reader. D1/S1 marks the southern and D2/S2 the northern parts of the intrusion, both located at shallow depth. S1 is more pronounced than S2, however, the magnetic anomaly is strongest in the area above S1. In contrast, the strongest gravity anomaly is found close to D2/S2. Between the D1/S1 and $\mathrm{D} 2 / \mathrm{S} 2$ anomalies, there seems to be, what is interpreted as a fenite unit that continues down to about $1000 \mathrm{~m}$ depth, with low density and susceptibility values; D1/S1 and D2/S2 merge to one body (D3/S3) at depth. Figures 11 and 12 show how the modelling results correlate with the highly reflective zone in the reflection seismic data (D3/S3). Generally, the dense and highly magnetic part of the intrusion is sub-vertical in the south along Alnö1 and Alnö3 (D1/S1 in Figures 11c, d and 12f, h). This is less obvious in the west along Alnö1 and Alnö2 where the density model indicates vertical geology whereas the susceptibility model indicates outward dipping (D2/S2 in Figures 11c, d and 12e, g). While the models along Alnö1 (Figure 
Solid Earth Discuss., doi:10.5194/se-2017-3, 2017

Manuscript under review for journal Solid Earth

Published: 23 January 2017

(c) Author(s) 2017. CC-BY 3.0 License.
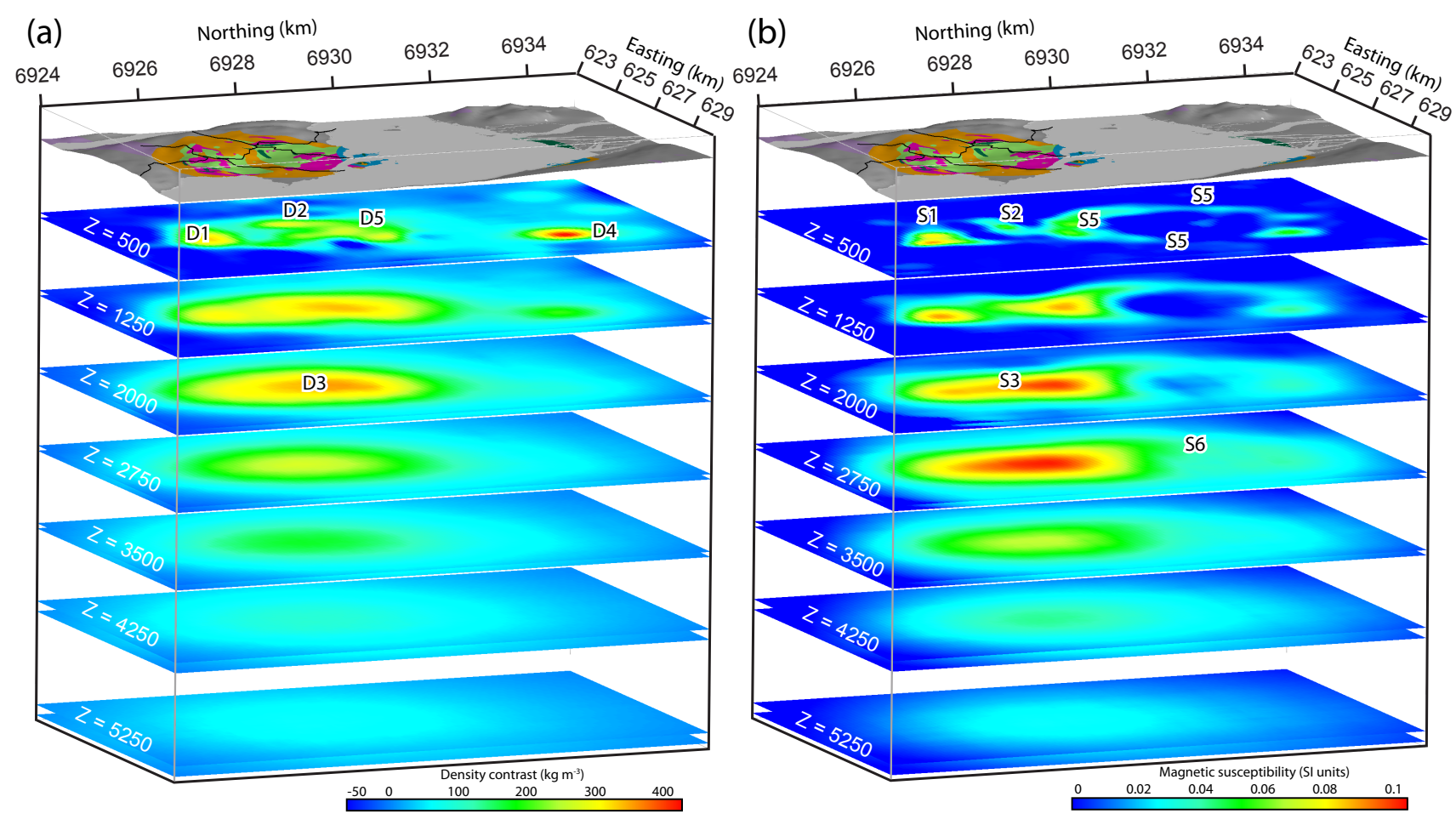

Figure 10. Depth slices of the inversion models. Oblique 3D view of the surface geological map of the study area and depth slices extracted from the 3D inversion models showing (a) density and (b) magnetic susceptibility. Both the gravity and the magnetic inversion models indicate that the main northern and southern intrusions merge at about $1 \mathrm{~km}$ depth (D1/S1 and D2/S2) and that it is unlikely that the intrusion continues below $3.5 \mathrm{~km}$ depth (D3/S3). For the area under the bay the magnetic model is more reliable than the density model because there are no gravity data points in the centre of the bay. The magnetic inversion model delineates a circular low-susceptibility body with a high-susceptibility rim (S5). The low-susceptibility body extends down to about $2 \mathrm{~km}$ depth where the higher susceptibility region (S6) appears. The density model indicates that the satellite-intrusion in Söråker (D4) does not extend as deep as the main intrusion in the Alnö Island. However, because the sea truncates this intrusion and the local anomaly is probably not fully represented in the data, it might be deeper than the inversion model suggests.

$12 \mathrm{c}, \mathrm{d})$ suggest an isolated feature that is surrounded by low density, low susceptibility rocks (i.e., migmatitic rocks), models along both Alnö2 and Alnö3 suggest that the complex continues further north under the Klingefjärden bay. High density and susceptibility materials in the north-eastern side of Alnö3 (Figure 13f, h) are gently dipping towards the bay.

A careful inspection of the results along Alnö1 indicates two distinct high density and susceptibility units that correspond,

5 on the surface, to alkaline rocks (ijolite and nepheline syenite). Ground magnetic measurements collected during the seismic survey (Figure 12a; see Andersson et al. (2013) suggest two long-wavelength anomalies and several smaller ones. The high susceptibilities in the central part of the line are associated with numerous carbonatite dykes observed in the surface geology 
Solid Earth Discuss., doi:10.5194/se-2017-3, 2017

Manuscript under review for journal Solid Earth

Published: 23 January 2017

(c) Author(s) 2017. CC-BY 3.0 License.

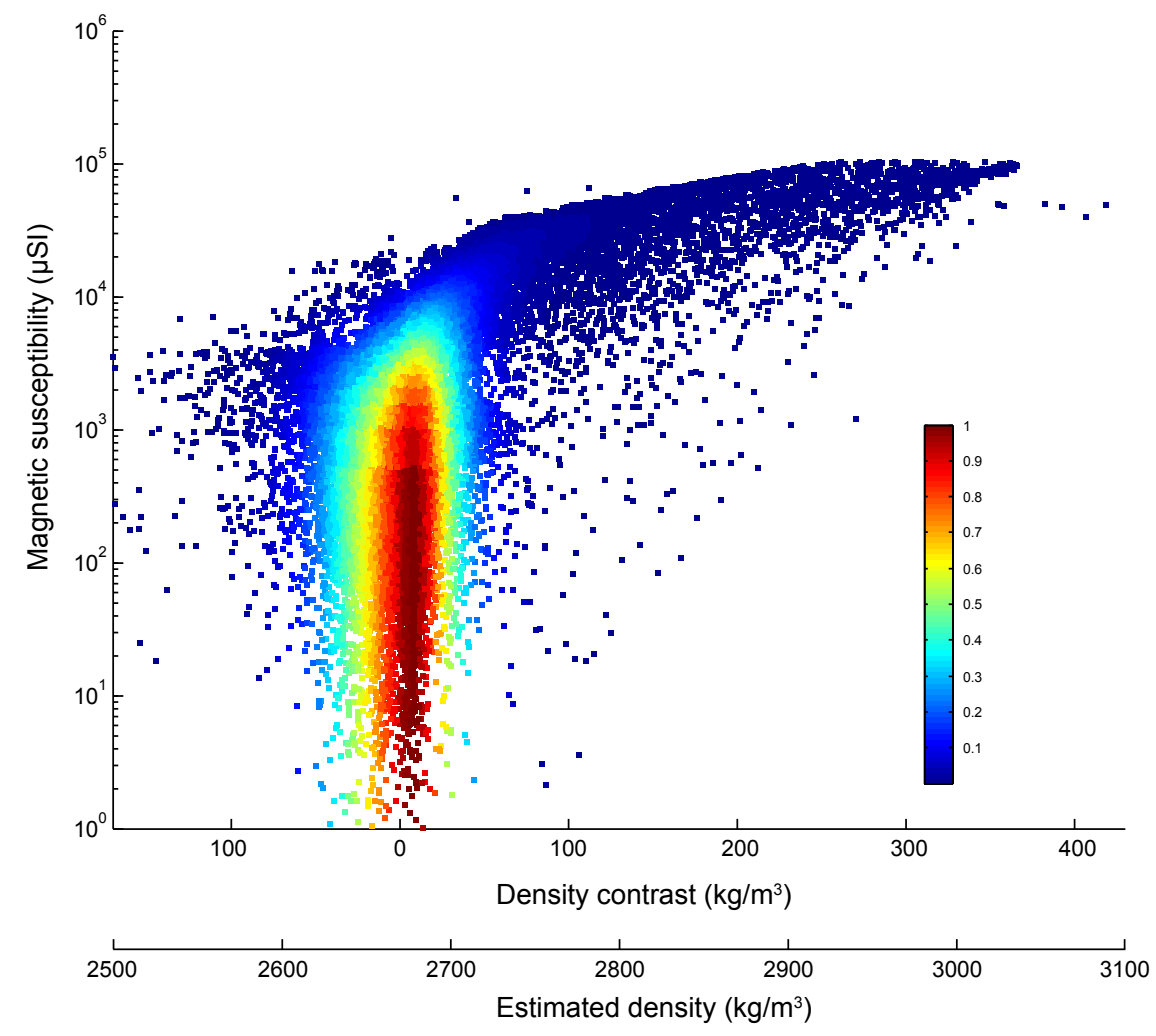

Figure 11. Scatter plot of the density and magnetic susceptibility for all grid cells in the gravity and magnetic inversion models. Data with zero-values of magnetic susceptibility were removed and remaining data set was decimated (1 in every 50 samples are shown) to avoid a cluttered graph. Colour coding is based on the data density. A total of 41616 data points are shown in the cross-plot.

(von Eckermann, 1948; Kresten, 1980, 1990; Andersson et al., 2013). Both dense and magnetic materials extend down to about 3-4 km depth and also suggest a region of low density and susceptibility interpreted to be fenite, in the central part of the line. A similar relationship between high density and susceptibility regions in the models and their corresponding surface geology is observed along Alnö2 and Alnö3. Some of the short-wavelength magnetic anomalies along these two lines are not properly the models and reflection seismic sections are observed, in particular along Alnö3 (Figure 13). Note that it is likely that the reflections have apparent dip due to the 3D geometry of the complex and thus might well be slightly steeper than they appear in the seismic sections. 
Solid Earth Discuss., doi:10.5194/se-2017-3, 2017

Manuscript under review for journal Solid Earth

Published: 23 January 2017

(c) Author(s) 2017. CC-BY 3.0 License.
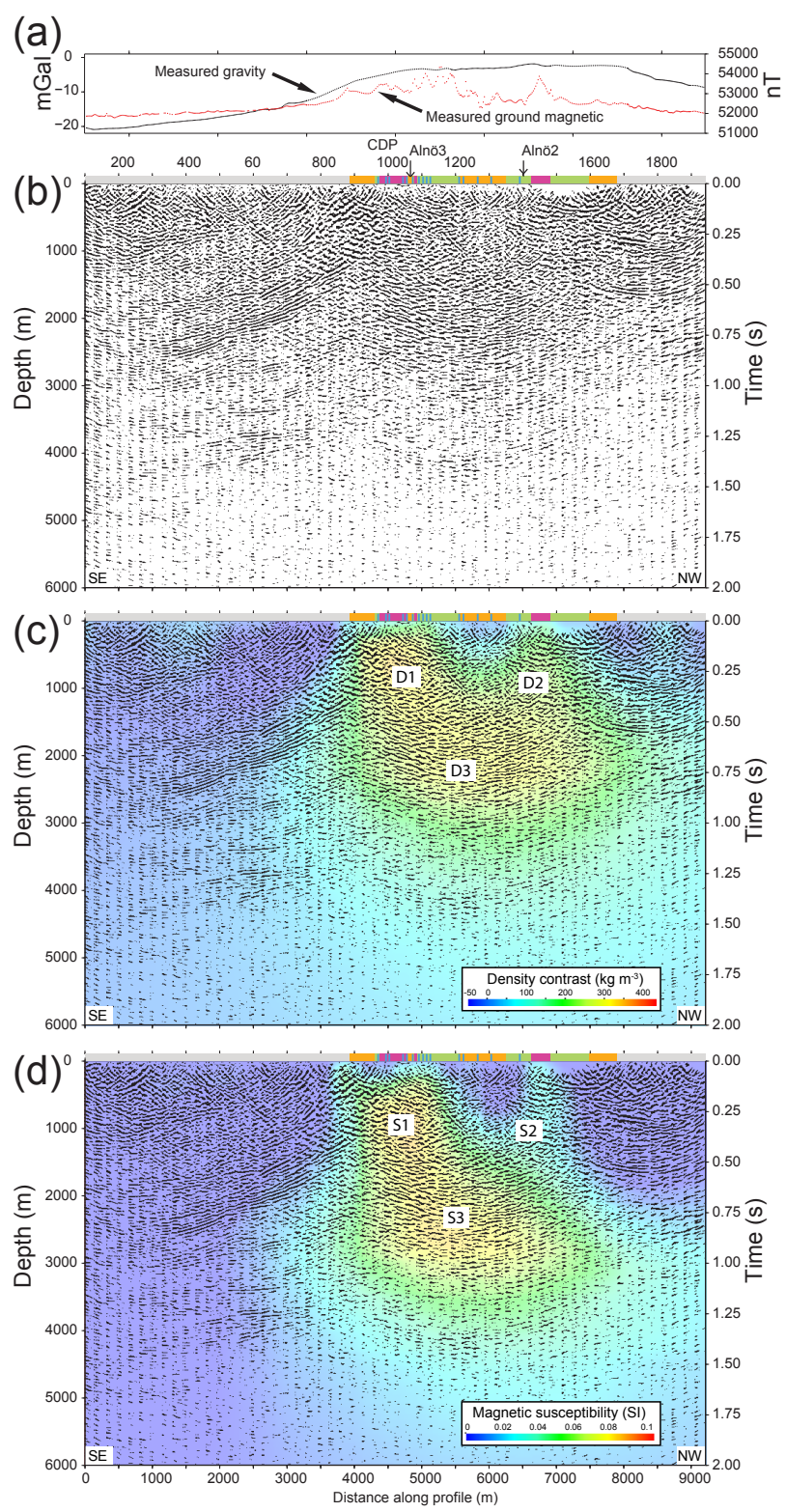

Figure 12. (a) Ground gravity and total-field magnetic measurements along the seismic profile Alnö1. (b) Post-stack depth migrated seismic section. Slices from the density (c) and susceptibility (d) models are shown along the seismic profile. See Figure 1 for the colour scheme representing surface geology at the top of the sections. 
Solid Earth Discuss., doi:10.5194/se-2017-3, 2017

Manuscript under review for journal Solid Earth

Published: 23 January 2017

(c) Author(s) 2017. CC-BY 3.0 License.

(a)

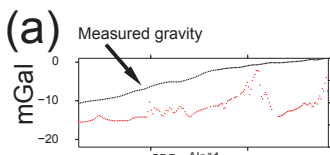

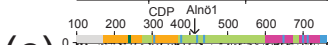

(c)

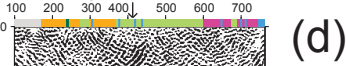
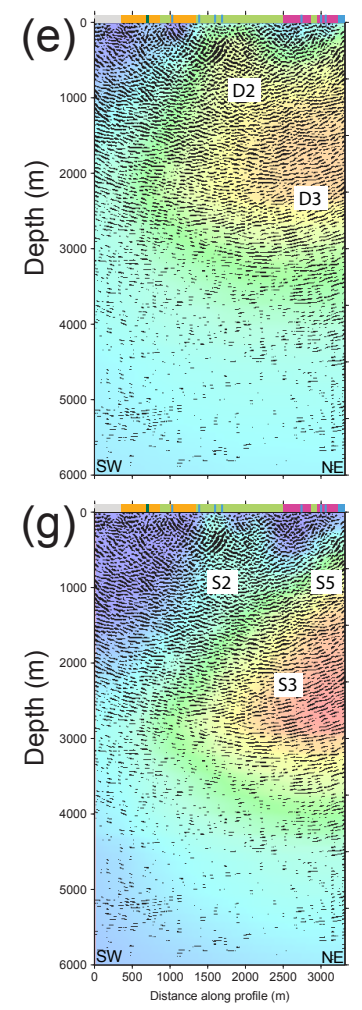

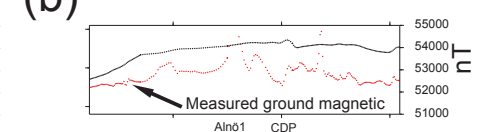

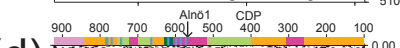

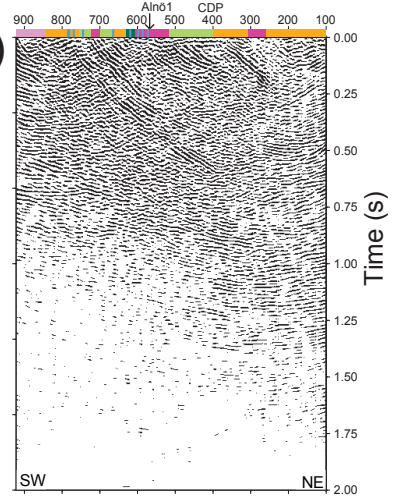

(f)

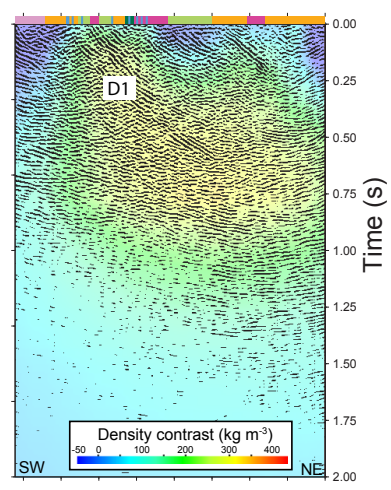

(b)

.

(3)

$\stackrel{\oplus}{\varepsilon}$

(1)

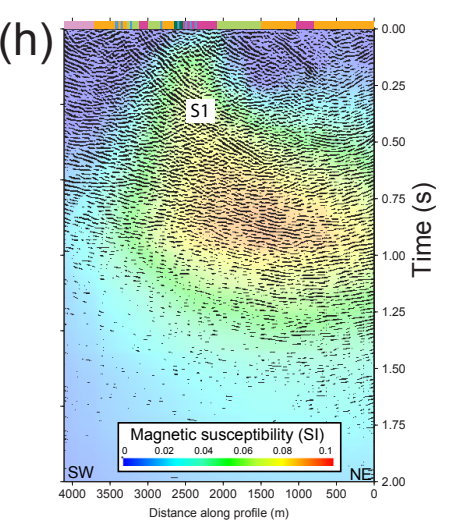

Figure 13. (a, b) Ground gravity and total-field magnetic measurements along the seismic profiles Alnö2 (left) and Alnö3 (right). (c, d) Poststack depth migrated seismic sections. Slices from the density $(\mathrm{e}, \mathrm{f})$ and susceptibility $(\mathrm{g}, \mathrm{h})$ models are shown along the seismic profiles. See Figure 1 for the colour scheme representing surface geology at the top of the sections. 
Solid Earth Discuss., doi:10.5194/se-2017-3, 2017

Manuscript under review for journal Solid Earth

Published: 23 January 2017

(c) Author(s) 2017. CC-BY 3.0 License.

\section{Discussion}

It is widely accepted that the inversion of potential field data leads to models which are non-unique and lack resolution at depth (Li and Oldenburg, 1996, 1998a). As well as this, given the many different rock types that occur in the Alnö area it is impossible to distinguish all of them using only potential field data. At best, one can separate them or group them together based on their common properties. However, if we bear this in mind when interpreting the results from this study, we can make inferences as to the plausible scenarios that can explain the internal architecture of this world-class carbonatite and alkaline complex. Note that these types of complexes are not only unique in terms of their petrology but also because they are sometimes rich in REEs (Rare Earth Elements) and apatite minerals, which are in high demand in today's society. In fact most REEs in the world are mined from carbonatites, e.g., Bayan Obo in China, Lovozero in Russia, Mount Weld in Australia, Mountain Pass in USA, and

10 Strange Lake in Canada (see Berger et al., 2009; Zaitsev et al., 2014), whereas Siilinjärvi carbonatite complex is an apatite mine in Finland (Malehmir et al., 2017). Therefore an estimate about their depth, lateral extent and the geological factors that have contributed to their formation can have implications for potential mineral resources. Our earlier studies using AMS data (Andersson et al., 2016) suggested that magnetite is a dominant magnetic mineral within the carbonatites that give rise to their high magnetic susceptibility (see also Malehmir et al., 2017). However, these types of rocks are not expected to comprise the main bulk volume of the complex and to produce the large positive gravity anomaly observed over the intrusion (Figure 2a).

\subsection{Fossil magma chamber}

On inspection of the gravity map, although no data are available for Klingefjärden bay itself, it is obvious that the gravity anomaly continues to the northwest all the way to the mainland on the northern side of the bay (Figure 6b). This indicates that the suggested solidified magma chamber may not be confined only within the main island but instead continues under the whole bay. Gravity and magnetic models, in conjunction with the reflection seismic data along Alnö2 (Figure 13), support this idea. Alternatively, it is possible that many pockets of magma in local reservoirs solidified and hence the gravity anomaly observed in the Alnö Island and the bay is the result of a combination of many small bodies. Mattsson et al. (2014) suggested the existence of many pockets of magma in the complex. However, a depth extent corresponding to $3-4 \mathrm{~km}$ is a valid scenario for the thickness of the complex and its associated lithologies (Figure 14). Given the small volume of carbonatite dykes compared with other lithologies at the surface, we believe the gravity and magnetic highs over the complex (Figure 2) are caused by a combination of nepheline syenite, ijolite, and carbonatite rocks (Figure 4). The high densities modelled from the gravity data also suggest a substantial volume of pyroxenite (or very dense materials) in the intrusion. Pyroxenites are not common within the intrusion at the surface (Figure 1), but when encountered often appear to be massive. Shallow magma chambers in modern volcanic settings are not uncommon, such as the Slaufrudalur pluton on Iceland (Burchardt et al., 2012). If the interpretation of a shallow magma chamber is correct, this may open possibilities to find similar situations in other places in the world (e.g., Oldoinyo Lengai). There has been speculation of whether the Alnö complex hosts any diamond-bearing alnöite rocks (Kresten and Nairis, 1983; Kresten, 1990), although to date no diamonds have been found. We believe a shallow magma chamber implies a slow emplacement process (not similar emplacement as observed for example for kimberlites or lamprophyres (e.g., 
Solid Earth Discuss., doi:10.5194/se-2017-3, 2017

Manuscript under review for journal Solid Earth

Published: 23 January 2017

(c) Author(s) 2017. CC-BY 3.0 License.

(a)

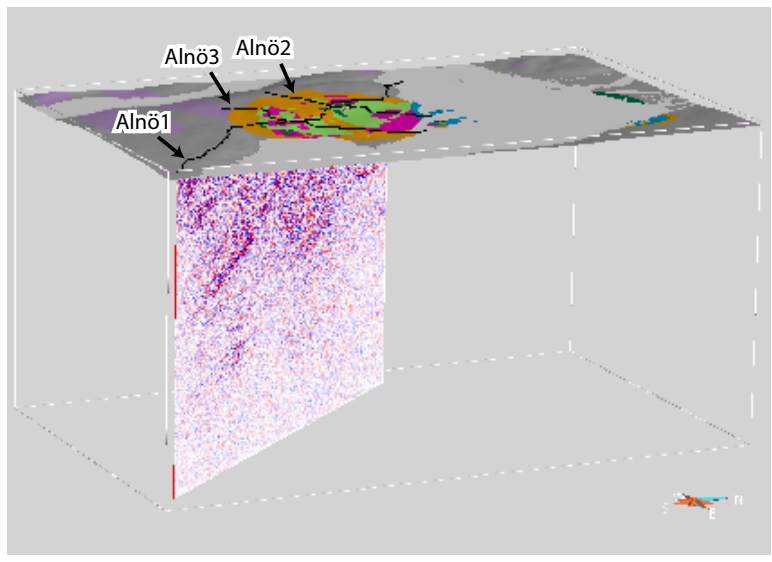

(c)

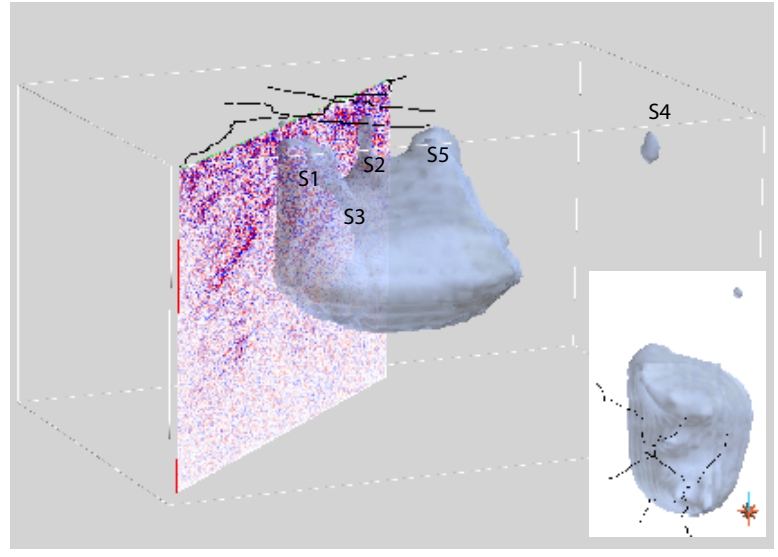

(b)

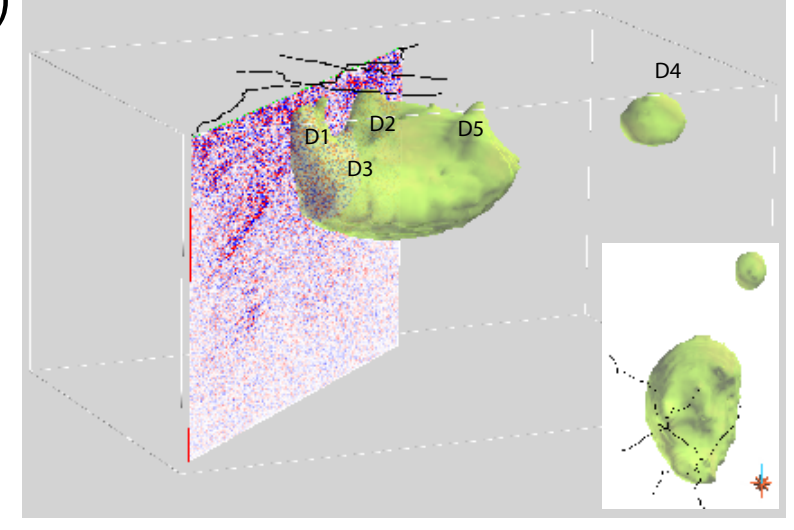

(d)

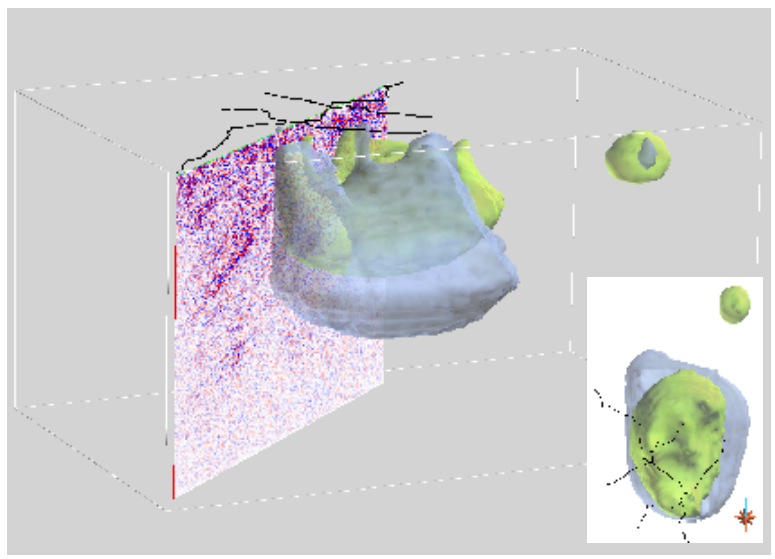

Figure 14. (a) Oblique 3D view of the geology of the northern part of the Alnö Island visualised with the $\sim 9 \mathrm{~km}$ long seismic section of Alnö1. (b) Oblique and top view of the iso-surface representing a relative density of $+250 \mathrm{~kg} / \mathrm{m}^{3}$ (or absolute density of about $2920 \mathrm{~kg} / \mathrm{m}^{3}$ ) from the 3D density model. (c) The iso-surface representing a susceptibility of 0.05 SI from the susceptibility model. (d) Same iso-surface as in (b) and (c) but visualised together. Both the density and susceptibility models indicate that the northern and southern parts of the intrusion connect at about 800-1000 m depth under the Alnö Island.

Sparks et al., 2006; Russell et al., 2012) and thus it is unlikely that diamond would be preserved during the transport to the surface (e.g., Andersson et al., 2013). However, to confirm this, temperature-pressure studies are required, which we highly recommend. There is currently no conclusive evidence if the alnöites and carbonatite dykes have a common origin, a matter that warrants further studies. 
Solid Earth Discuss., doi:10.5194/se-2017-3, 2017

Manuscript under review for journal Solid Earth

Published: 23 January 2017

(c) Author(s) 2017. CC-BY 3.0 License.

\subsection{Magnetic ring-structure in the bay and possible scenarios}

Earlier studies have speculated about a possible caldera centre (with various dimension) somewhere in the Klingefjärden bay (Kresten, 1990; Andersson et al., 2013). The main support for this has been the discovery of the large boulders with accretionary lapillis at the Sälskär skerries (Figure 3c, d) suggesting surficial volcanic activities associated with the main intrusion (Kresten, 1990). The magnetic ring-structure (Figure 2b) observed in the bay is perhaps the most spectacular and large-scale ( $3 \mathrm{~km}$ diameter) feature observed in the area. Water depth varies in the bay from a few meters between the small islands and close to shorelines to 40-50 $\mathrm{m}$ in the deepest parts of the bay (Figure 1). Thus the magnetic ring-structure is not an effect from the water depth and represents a true geology. The ring is characterized by a low magnetic anomaly in the middle and a magnetic high around its rim. There is also a linear magnetic feature within the northern part of the ring with a WNW-ESE strike, which seems to be an internal structure because it is not visible outside of the ring.

Our petrophysical data are limited to the islands in the southern part of the ring-shaped magnetic anomaly (Figure 1). The ring-shape continues around the bay, however, it is less pronounced but still visible on the eastern side of it (Figure $2 b$ ). The massive carbonatites from Hörningsholmen to Sälskär skerries in the south and the Söråker intrusion on the northern side of the bay may be outcrops of a carbonatite ring structure. An intrusion centre in the bay was first suggested by von Eckermann (1948) but later questioned by (Kresten, 1980) from the analysis of the dyke geometries. We present four scenarios that can explain the shape of the underlying geology producing the magnetic ring-shaped structure generated using various iso-surfaces from the magnetic susceptibility model (Figure 15):

- Scenario A with lowest magnetic susceptibility (>0.01 SI) shows a bowl-shaped magnetic body that is connected to the main intrusion on the island, underlying almost the entire bay area (S4 and S5 in Figure 15a).

- Scenario B (>0.02 SI) gives a similar shape but with a more narrow "wall" for the bowl (Figure 15b).

- In scenario C (>0.03 SI), the whole "wall" of the bowl disappears except in the southern side of the bay (the small islands north of the Alnö Island) and in the northern side of the bay (Söråker intrusion). The sub-horizontal magnetically susceptible solidified magma chamber stretch across the bay at about $3 \mathrm{~km}$ depth (S6 in Figure 15c). At Söråker, the intrusion (S4) connects down to the interpreted magma chamber (S6).

- In scenario D (>0.04 SI), the solidified magma chamber (S6) totally disappears in the northern part of the bay and shows the Söråker intrusion as a solitary satellite intrusion (S4). The assumption of such a high susceptibility is probably not justified and is not consistent with the gravity high observed on the northern side of the bay.

From these, we prefer scenarios B and C. The rim would then comprise of a mixture of carbonatite and alkaline rocks, as the petrophysical data suggest high magnetic susceptibility for these rocks. Questions that still remain are: what constitutes the inner part of the ring and the "bowl" in the magnetic susceptibility model? Could the ring simply be a cone-sheet intrusion surrounding migmatite or fenite connecting at depth to the main magma chamber? Is this evidence for a large collapsed caldera structure where the ring-shape relates to a ring-dyke system? Could this simply be a Rödön rapakivi granite intrusion as also observed in the south-eastern part of the study area (Figure $2 b$ )? 
Solid Earth Discuss., doi:10.5194/se-2017-3, 2017

Manuscript under review for journal Solid Earth

Published: 23 January 2017

(c) Author(s) 2017. CC-BY 3.0 License.
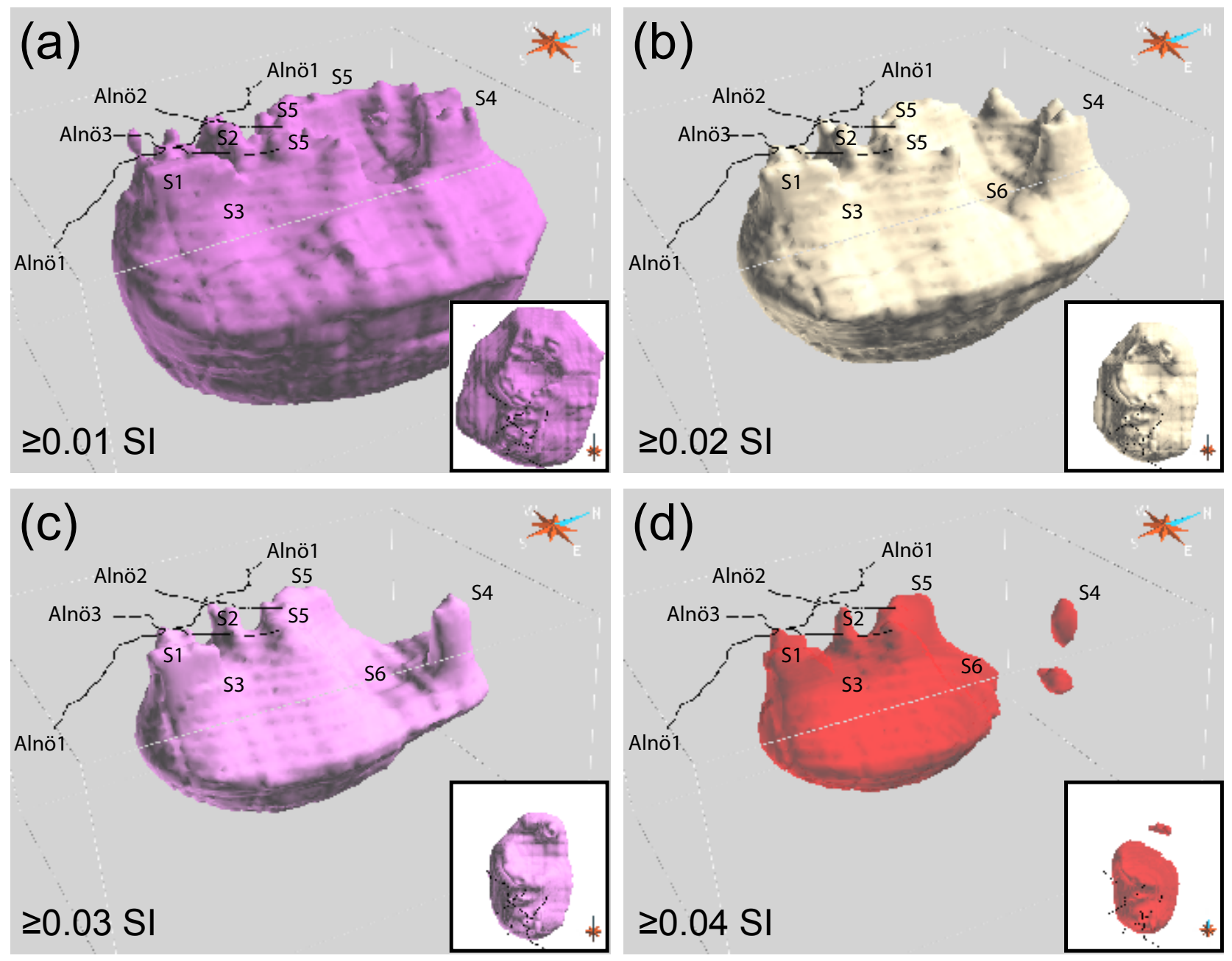

Figure 15. Four scenarios with iso-surfaces representing different sizes of the ring-shaped magnetic body (cf. Figure 2). (a) Iso-surface representing a susceptibility of $0.01 \mathrm{SI}$, (b) Iso-surface representing a susceptibility of $0.02 \mathrm{SI}$, (c) Iso-surface representing a susceptibility of $0.03 \mathrm{SI}$, and (d) Iso-surface representing a susceptibility of $0.04 \mathrm{SI}$. The preferred scenarios to explain the 3D geometry of the ring-shaped magnetic anomaly in the bay are (b) and (c).

It is easy to reject the presence of a highly magnetic Rödön type granitic intrusion in the vicinity of the Alnö complex. These granitic intrusions are much older than the Alnö complex ( 1500 Ma; Welin, 1994; Andersson, 1997) thus should not cross-cut the complex. The magnetic ring-shaped structure appears to be younger and perhaps even cuts the Alnö main intrusion at its northern margin (where Alnö2 ends in the north; Figure 1). In addition, the Rödön-type granites are typically homogeneously magnetic (Figure 2b), not just at their margins, which further suggests that the ring is unlikely to be a granitic intrusion. It 
Solid Earth Discuss., doi:10.5194/se-2017-3, 2017

Manuscript under review for journal Solid Earth

Published: 23 January 2017

(c) Author(s) 2017. CC-BY 3.0 License.

is however possible that a massive alkaline intrusion similar to those observed in South Africa (e.g., Pilanesberg; Kiefer and Viljoen, 2006) is responsible for the magnetic low within the rim. A simple cone-sheet intrusion is possible but unlikely since such a large symmetrical structure has not yet been identified on the main island. Among all the four possible scenarios, we favour a large caldera with collapsed structures in the middle. In this scenario, the magnetic ring-structure was likely formed at the latest stage of magmatic activities in the complex and a large volume of carbonatite rocks were erupted to the surface (or near the surface) in ring-dykes, which led to a pressure drop in the magma chamber and formed the caldera. The caldera collapse must have been preceded by intense sheet intrusion with low-magnetic, probably alkaline, magma whereas the caldera collapse have brought a new generation of magnetic magma. A similar magnetic ring-shape is expressed over the Richat Dome (Mauritania) and has been interpreted to relate to ring-dykes from a piston-like caldera collapse, however Richat Dome has two concentric ring-dykes and they are of gabbroic composition (Matton and Jébrak, 2014).

\subsection{The main Alnö intrusion and possible scenarios}

All different rock types in the cross-plot of petrophysical data from Alnö plot somewhere along Trend 1, carbonatite and nepheline syenite along Trend 2 and some carbonatite alone along Trend 3 (Figure 4). The cross-plot of density and susceptibility of the data from the inversion models (Figure 11) shows two trends that resemble Trends 2 and 3 observed in Figure 4, while no data in the models follow Trend 1. We present two scenarios for the emplacement of the Alnö intrusion:

- Scenario 1 (carbonatite rocks): the carbonatites are the main reason for both gravity and magnetic anomalies as they plot along Trend 3 in Figure 4.

- Scenario 2 (alkaline rocks): the major parts of the magnetic and gravity anomalies come from the alkaline rocks such as ijolite, nepheline syenite, and pyroxenite and a minor part from carbonatites, as carbonatites must represent a smaller volume compare to their parental magma.

Carbonatite is overrepresented in the petrophysical data due to the focus on dykes and sheets in the AMS study by Andersson et al. (2016). However, as no other rock types follow Trend 3, the gravity and magnetic anomalies could possibly be caused by carbonatites (favouring scenario 1). Nevertheless, the geological mapping of Alnö clearly shows that carbonatites are only represented by a small fraction at the surface. Furthermore, and maybe more importantly, the carbonatite magma has probably evolved from a parental alkaline magma. Various processes have been suggested to produce carbonatites but magma immiscibility of alkaline silicate and carbonatite liquids or fractional crystallisation are probably the most likely (Treiman and Essene, 1985; Le Bas, 1987; Gittins, 1988; Vuorinen and Skelton, 2004; Brooker and Kjarsgaard, 2010). Also a direct derivation of carbonatite magma from the mantle have been suggested, because carbonatites occur without associated igneous silicate rocks (24\% of the locations in the world) (Woolley and Kjarsgaard, 2008). However, the main intrusion at Alnö obviously holds carbonatite rocks associated with alkaline rocks. Assuming a petrogenetic association between the carbonatite and alkaline silicate rocks, the parental magma (alkaline silicates) must have been more voluminous than the carbonatite magma that is produced from it. This therefore favours the second scenario, which means that alkaline silicate rocks are the main cause for the gravity and magnetic anomalies in the Alnö complex. 
Solid Earth Discuss., doi:10.5194/se-2017-3, 2017

Manuscript under review for journal Solid Earth

Published: 23 January 2017

(c) Author(s) 2017. CC-BY 3.0 License.

The inversion of gravity and magnetic data are done separately and it can be problematic to compare the models as done using the cross-plot shown in Figure 11. The density points following Trend 3 (Figure 11) could be shifted down to align with Trend 1 instead. This means the presence of alkaline rocks could be used to explain the gravity anomaly (Figure 4). However, rocks with high susceptibility must still be present (e.g., carbonatites) if this was the case. Thus only a limited amount of alkaline rocks would be needed to explain the data.

From the results of the remanent magnetisation (NRM) and Königsberger ratio, generally $\mathrm{Q}<1$, we made the assumption that the remanence has a minor influence on the inversion model. However, because the NRM is for most samples parallel to the Earth's magnetic field, the inversion model overestimates the magnetic materials in the subsurface. Further, the samples that show most remanence are fine-grained carbonatites, which mainly occur in narrow dykes $(<0.3 \mathrm{~m})$ and do not make up a significant portion of the rock volume of outcrops that have been mapped in the area.

\subsection{Recommendations for future studies}

For more than a century, the Alnö complex in the main island has been the focus of several geological studies, and recently also geophysical ones. It is clear that in order to better understand the emplacement of the Alnö complex, a much larger survey covering the bay should also be conducted. Access to the bay is not straightforward due to various environmental and logistical issues. While outcrops are rare in the bay, marine geophysical data may be optimal but certainly expensive to acquire. It is therefore recommended that a couple of deep boreholes ( $2-3 \mathrm{~km}$ depth) are drilled from the Alnö Island or from mainland in Söråker, which target the magnetic ring-shaped structure and its surrounding rock units. This would help to better understand the connection between the intrusion and any volcanic activities which occurred in the bay area. It will also allow direct access to the lithological units and allow their physical and chemical properties to be studied. Boreholes targeting the central part of the intrusion would also be beneficial especially if inclined, so that the outward dipping reflectors surrounding the main intrusion and then the central part of the intrusion would be intersected. The Swedish Scientific Deep Drilling has been launched with a rig capable of drilling down to about $2.5-3 \mathrm{~km}$ depth (Lorenz, 2010) thus providing an opportunity to answer some of the questions raised in this study as well as earlier ones that can be addressed by drilling. Future studies can also benefit from some marine gravity and magnetic measurements to provide even higher resolution data for potential field modelling. Deep penetrating airborne electromagnetic surveys can also be performed, bearing in mind that it might fail due to the water salinity in the bay. Joint inversion of gravity and magnetic data (Gallardo-Delgado et al., 2003) can be carried out to better constrain the results presented here and their interpretations.

\section{Conclusions}

The potential field modelling results for the main intrusion on Alnö Island indicate two separate regions within the intrusion that are associated with gravity and magnetic highs, which are likely to be connected at depths of about 800-1000 m. This implies a common source for the rocks observed in these two regions. The models also indicate that the complex and its associated lithologies have a depth extent of about 3-4 km below the present-day surface, which is consistent with the earlier interpretation 
Solid Earth Discuss., doi:10.5194/se-2017-3, 2017

Manuscript under review for journal Solid Earth

Published: 23 January 2017

(c) Author(s) 2017. CC-BY 3.0 License.

of the reflection seismic data, suggesting a palaeo-magma chamber at this depth range. The ring-shaped magnetic anomaly in the Klingefjärden bay is probably generated from carbonatite rocks with extremely high magnetic susceptibility. It may also include a substantial amount of alkaline rocks, since carbonatites are often genetically linked with alkaline rocks. Five separate intrusions have been indicated to exist within the Alnö complex, namely the Southern intrusion, the Northern intrusion, the Båräng intrusion, the Söråker intrusion, and the Sälskär intrusion, which lies below the sea water, close to Sälskär skerries. Boulders of lapilli-breccias are found in the Sälskär skerries. The ring-shaped magnetic anomaly coincides with the Northern-, the Söråker-, and the Sälskär-intrusions. In earlier studies, the Söråker intrusion was suggested to be a satellite intrusion about $3 \mathrm{~km}$ north of the complex. Although the gravity data points are limited in the Klingefjärden bay, the positive gravity anomaly is likely to continue on the northern side of the bay. This implies high-density materials, of Alnö type rocks, to extend in the subsurface to the other side of the bay. We propose a scenario with a large caldera, with collapsed structures $(\sim 3 \mathrm{~km}$ radius $)$ in the middle. The magnetic ring-shaped structure was likely formed at the latest stage of magmatic activities in the complex when a large volume of carbonatite rocks was erupted to the surface (or near the surface). This led to a pressure drop in the magma chamber and formed the caldera. The periphery of the caldera is delineated by the high magnetic ring-shaped anomaly. The 3D magnetic model also indicates that the magma chamber under the Alnö Island may continue further north (across the bay) and link the Söråker intrusion to the main complex. Acquisition of more geophysical data in the bay and eventually a deep drilling program would be required to validate these interpretations and to assess the potential for possible REE resources in the carbonatites. Until then, this study provides the most extensive and detailed information to date, about the possible relationship between the main intrusion in the Alnö Island and carbonatites found in the bay and north of it.

\section{Data availability}

20 Parts of the data are available as supplementary materials. However, data made available by the Geological Survey of Sweden (aeromagnetic and some of the gravity data) are not provided due to permission issues.

Author contributions. A. Malehmir initiated the project and suggested the idea of performing 3D gravity and magnetic data modelling in the Alnö complex. M. Andersson run the inversions and created the illustrations. Both authors were involved in the interpretation and writing of the manuscript.

Acknowledgements. The Geological Survey of Sweden (SGU) provided aeromagnetic and some of the ground gravity data, as well as their facilities to measure bulk magnetic susceptibility and magnetic remanence. Lund University let us use their KLY-2 Kappabridge ${ }^{\mathrm{TM}}$ and the M2900-2 ${ }^{\mathrm{TM}}$ in the Palaeomagnetic and Mineral Magnetic Laboratory. GRAV3D ${ }^{\mathrm{TM}}$ and MAG3D ${ }^{\mathrm{TM}}$ were used to model the potential field data for which we are grateful. Mira Geoscience provided their Mining Suite package to visualize the models in $\mathrm{gOcad}^{\mathrm{TM}}$ for which we are 
Solid Earth Discuss., doi:10.5194/se-2017-3, 2017

Manuscript under review for journal Solid Earth

Published: 23 January 2017

(c) Author(s) 2017. CC-BY 3.0 License.

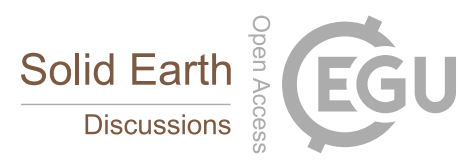

(c) (i)

thankful. B. Almqvist provided help with some of the property measurements and commented on an earlier version of this paper for which we are thankful. The Swedish Research Council (VR) funded this study (project 621-2009-4439). 
Solid Earth Discuss., doi:10.5194/se-2017-3, 2017

Manuscript under review for journal Solid Earth

Published: 23 January 2017

(c) Author(s) 2017. CC-BY 3.0 License.

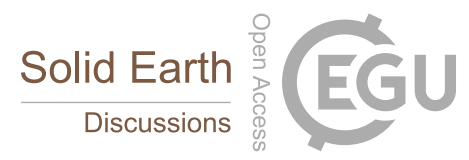

(c) (i)

\section{References}

Andersson, M., Malehmir, A., Troll, V. R., Dehghannejad, M., Juhlin, C., and Ask, M.: Carbonatite ring-complexes explained by caldera-style volcanism, Sci. Rep., 3, 1-9, doi:10.1038/srep01677, http://www.nature.com/articles/srep01677, 2013.

Andersson, M., Almqvist, B. S., Burchardt, S., Troll, V. R., Malehmir, A., Snowball, I., and Kübler, L.: Magma transport in sheet intrusions of the Alnö carbonatite complex, central Sweden, doi:10.1038/srep27635, http://www.nature.com/articles/srep27635, 2016.

Andersson, U. B.: Petrogenesis of some Proterozoic granitoid suites and associated basic rocks in Sweden (Geochemistry and Isotope Geology), Sveriges Geol. undersökning, Rm 91, 1-216, 1997.

Berger, V., Singer, D., and Orris, G.: Carbonatites of the World, Explored Deposits of Nb and REE - database and Grade and Tonnage Models, Tech. rep., U.S. Geological Service, Reston, 2009.

Brooker, R. A. and Kjarsgaard, B. A.: Silicate-Carbonate Liquid Immiscibility and Phase Relations in the System SiO2-Na2O-A12O3-CaOCO2 at 0·1-2.5 GPa with Applications to Carbonatite Genesis, J. Petrol., 52, 1281-1305, doi:10.1093/petrology/egq081, http://www. petrology.oxfordjournals.org/cgi/doi/10.1093/petrology/egq081, 2010.

Burchardt, S., Tanner, D., and Krumbholz, M.: The Slaufrudalur pluton, southeast Iceland - An example of shallow magma emplacement by coupled cauldron subsidence and magmatic stoping, Geol. Soc. Am. Bull., 124, 213-227, doi:10.1130/B30430.1, http:/gsabulletin. gsapubs.org/cgi/doi/10.1130/B30430.1, 2012.

Dawson, J. B.: The geology of Oldoinyo Lengai, Bull. Volcanol., 24, 349-387, doi:10.1007/BF02599356, http://link.springer.com/10.1007/ BF02599356, 1962.

Dawson, J. B., Pinkerton, H., Norton, G. E., and Pyle, D. M.: Physicochemical properties of alkali carbonatite lavas:Data from the 1988 eruption of Oldoinyo Lengai, Tanzania, Geology, 18, 260, doi:10.1130/0091-7613(1990)018<0260:PPOACL>2.3.CO;2, http://geology.gsapubs.org/content/18/3/260.shorthttp://geology.gsapubs.org/cgi/doi/10.1130/0091-7613(1990)018\{\%\}3C0260:

PPOACL\{\%\}3E2.3.CO;2, 1990.

Dutra, A. C. and Marangoni, Y. R.: Gravity and magnetic 3D inversion of Morro do Engenho complex, Central Brazil, J. South Am. Earth Sci., 28, 193-203, doi:10.1016/j.jsames.2009.02.006, http://linkinghub.elsevier.com/retrieve/pii/S0895981109000212, 2009.

Gallardo-Delgado, L. A., Perez-Flores, M. A., and Gomez-Trevino, E.: A versatile algorithm for joint 3D inversion of gravity and magnetic data, Geophysics, 68, 949, doi:10.1190/1.1581067, 2003.

Gittins, J.: The origin of carbonatites, Nature, 335, 295-296, doi:10.1038/335295a0, 1988.

Hedin, P., Malehmir, A., Gee, D. G., Juhlin, C., and Dyrelius, D.: 3D interpretation by integrating seismic and potential field data in the vicinity of the proposed COSC-1 drill site, central Swedish Caledonides, Geol. Soc. London, Spec. Publ., 390, 301-319, doi:10.1144/SP390.15, http://sp.lyellcollection.org/cgi/doi/10.1144/SP390.15, 2013.

Högbom, A.: Ueber das Nephelinsyenitgebiet auf der Insel Alnö, GFF, http://www.tandfonline.com/doi/pdf/10.1080/11035899509453263, 1895.

Kiefer, R. and Viljoen, M.: PGE exploration targets to the west of the Pilanesberg, South Africa, South Africa J. Geol., 109, 459-474, 2006. Kresten, P.: The Alnö Complex, in: Nord. Carbonatite Symp. Alnö, 1979.

Kresten, P.: The Alnö complex: tectonics of dyke emplacement, Lithos, 13, 153-158, 1980.

Kresten, P.: The Alnö Area (Alnöområdet), in: Beskr. till berggrundskartan över Västernorrlands län, chap. The Alnö A, pp. 238-278, Sveriges Geologiska Undersökning (SGU), Uppsala, 1990. 
Solid Earth Discuss., doi:10.5194/se-2017-3, 2017

Manuscript under review for journal Solid Earth

Published: 23 January 2017

(c) Author(s) 2017. CC-BY 3.0 License.

Kresten, P. and Morogan, V.: Fenitization at the Fen complex, southern Norway, Lithos, 19, 27-42, doi:10.1016/0024-4937(86)90013-7, 1986.

Kresten, P. and Nairis, H. J.: Alnö diamonds, GFF, 104, 210, http://www.tandfonline.com/doi/pdf/10.1080/11035898309455256, 1983.

Le Bas, M.: Nephelinites and carbonatites, Geol. Soc. London, Spec. Publ., 30, 53-83, doi:10.1144/GSL.SP.1987.030.01.05, 1987.

5 Le Maitre, R. W., Streckeisen, A., Zanettin, B., Le Bas, M., Bonin, B., Bateman, P., Bellieni, G., Dudek, A., Efremova, S., Keller, J., Lameyre, J., Sabine, P. A., Schmid, R., Sorensen, H., and Woolley, A. R.: Igneous Rocks: A Classification and Glossary of Terms, Cambridge University Press, 2002.

Li, Y. and Oldenburg, D. W.: 3-D inversion of magnetic data, Geophysics, 61, 394-408, 1996.

Li, Y. and Oldenburg, D. W.: 3-D inversion of gravity data, Geophysics, 63, 109-119, http://library.seg.org/doi/abs/10.1190/1.1444302, 1998a.

Li, Y. and Oldenburg, D. W.: Separation of regional and residual magnetic field data, Geophysics, 63, 431-439, 1998b.

Lorenz, H.: The Swedish Deep Drilling Program: For Science and Society, Gff, 132, 25-27, doi:10.1080/11035891003763354, 2010.

Lundqvist, T., Gee, D. G., Kumpulainen, R., Karis, L., and Kresten, P.: Beskrivning till berggrundskartan över Västernorrlands län, SGU, Uppsala, 1990.

15 Malehmir, A., Thunehed, H., and Tryggvason, A.: Case History The Paleoproterozoic Kristineberg mining area , northern Sweden : Results from integrated 3D geophysical and geologic modeling, and implications for targeting ore deposits, Geophysics, 74, B9-B22, 2009.

Malehmir, A., Andersson, M., Lebedev, M., Urosevic, M., and Mikhaltsevitch, V.: Experimental estimation of velocities and anisotropy of a series of Swedish crystalline rocks and ores, Geophys. Prospect., 61, 153-167, doi:10.1111/j.1365-2478.2012.01063.x, http://doi.wiley. com/10.1111/j.1365-2478.2012.01063.x, 2013.

Malehmir, A., Andersson, M., Mehta, S., Brodic, B., Munier, R., Place, J., Maries, G., Smith, C., Kamm, J., Bastani, M., Mikko, H., and Lund, B.: Post-glacial reactivation of the Bollnäs fault, central Sweden - A multidisciplinary geophysical investigation, Solid Earth, 7, 509-527, doi:10.5194/se-7-509-2016, 2016.

Malehmir, A., Heinonen, S., Dehghannejad, M., Heino, P., Maries, G., Karell, F., Suikkanen, M., and Salo, A.: Landstreamer seismics and physical property measurements in the Siilinjärvi open-pit apatite (Phosphate) mine, central Finland., Geophysics, pp. xx-xx, 2017.

Matton, G. and Jébrak, M.: The "eye of Africa" (Richat dome, Mauritania): An isolated Cretaceous alkaline-hydrothermal complex, J. African Earth Sci., doi:10.1016/j.jafrearsci.2014.04.006, http://www.sciencedirect.com/science/article/pii/S1464343X14000971, 2014.

Mattsson, H. B. and Vuorinen, J. H.: Emplacement and inflation of natrocarbonatitic lava flows during the March-April 2006 eruption of Oldoinyo Lengai, Tanzania, Bull. Volcanol., 71, 301-311, doi:10.1007/s00445-008-0224-z, http://link.springer.com/10.1007/ s00445-008-0224-z, 2008.

Mattsson, T., Burchardt, S., Troll, V. R., and Kresten, P.: The sub-volcanic structure of the Alnö carbonatite complex, Sweden, vol. 16, EGU General Assembly 2014, http://meetingorganizer.copernicus.org/EGU2014/EGU2014-16633.pdf, 2014.

Meert, J. G., Walderhaug, H. J., Torsvik, T. H., and Hendriks, B. W. H.: Age and paleomagnetic signature of the Aln $\varnothing$ carbonatite complex (NE Sweden): Additional controversy for the Neoproterozoic paleoposition of Baltica, Precambrian Res., 154, 159-174, doi:10.1016/j.precamres.2006.12.008, http://linkinghub.elsevier.com/retrieve/pii/S0301926807000095, 2007.

Meixner, T. and Lane, R.: 3D inversion of gravity and magnetic data for the Tanami region, in: Annu. Geosci. Explor. Semin., http://www. geoscience.nt.gov.au/gemis/ntgsjspui/bitstream/1/81529/1/NTGSRec2005-001.pdf, 2005.

Morogan, V.: Mass transfer and REE mobility during fenitization at Alnö, Sweden, Contrib. to Mineral. Petrol., 103, 25-34, http://link. springer.com/article/10.1007/BF00371362, 1989. 
Solid Earth Discuss., doi:10.5194/se-2017-3, 2017

Manuscript under review for journal Solid Earth

Published: 23 January 2017

(c) Author(s) 2017. CC-BY 3.0 License.

Morogan, V. and Lindblom, S.: Volatiles associated with the alkaline - carbonatite magmatism at Alnö, Sweden: a study of fluid and solid inclusions in minerals from the Långarsholmen ring complex, Contrib. to Mineral. Petrol., 122, 262-274, 1995.

Morogan, V. and Woolley, A. R.: Fenitization at the Alnö carbonatite complex, Sweden; distribution, mineralogy and genesis, Contrib. to Mineral. Petrol., 100, 169-182, 1988.

5 Nabighian, M. N., Grauch, V. J. S., Hansen, R. O., LaFehr, T. R., Li, Y., Peirce, J. W., Phillips, J. D., and Ruder, M. E.: Historical development of the magnetic method in exploration, Geophysics, 70, 33ND-61ND, doi:10.1190/1.2133785, 2005.

NOAA: NGDC Geomagnetic Calculators I ngdc.noaa.gov, http://www.ngdc.noaa.gov/geomag-web/?model=igrf, 2015.

Oldenburg, D. W., Li, Y., and Ellis, R. G.: Inversion of geophysical data over a copper gold porphyry deposit: A case history for Mt. Milligan, Geophysics, 62, 1419-1431, doi:10.1190/1.1444246, http://library.seg.org/doi/abs/10.1190/1.1444246, 1997.

Piper, J. D. A.: Magnetic properties of the Alnön Complex, GFF, 103, 9-15, 1981.

Puranen, R., Sulkanen, K., Poikonen, A., Nissinen, R., Simelius, P., and Harinen, L.: User's manual for a computerized petrophysics laboratory, Tech. rep., Geological Survey of Finland, http://tupa.gtk.fi/raportti/arkisto/q19_1_27_93_1.pdf, 1993.

Roy, B. and Clowes, R. M.: Seismic and potential-field imaging of the Guichon Creek batholith, British Columbia, Canada, to delineate structures hosting porphyry copper deposits, Geophysics, 65, 1418-1434, doi:10.1190/1.1444831, http://library.seg.org/doi/abs/10.1190/ $1.1444831,2000$.

Russell, J. K., Porritt, L. a., Lavallée, Y., and Dingwell, D. B.: Kimberlite ascent by assimilation-fuelled buoyancy., Nature, 481, 352-6, doi:10.1038/nature10740, http://www.ncbi.nlm.nih.gov/pubmed/22258614, 2012.

Skelton, A. D. L., Hode Vuorinen, J., Arghe, F., and Fallick, A.: Fluid-rock interaction at a carbonatite-gneiss contact, Alnö, Sweden, Contrib. to Mineral. Petrol., 154, 75-90, doi:10.1007/s00410-007-0180-1, http://link.springer.com/10.1007/s00410-007-0180-1, 2007.

Sparks, R. S. J., Baker, L., Brown, R. J., Field, M., Schumacher, J., Stripp, G., and Walters, A.: Dynamical constraints on kimberlite volcanism, J. Volcanol. Geotherm. Res., 155, 18-48, 2006.

Tarling, D. H. and Hrouda, F.: Magnetic Anisotropy of Rocks, Chapman \& Hall, London, 1993.

Treiman, A. H. and Essene, E. J.: The Oka carbonatite complex , Quebec: geology and evidence for silicate-carbonate liquid immiscibility, Am. Mineral., 70, 1101-1113, 1985.

25 Treiman, A. H. and Schedl, A.: Properties of carbonatite magma and processes in carbonatite magma chambers, J. Geol., 91, 437-447, http://www.jstor.org/stable/30064002, 1983.

von Eckermann, H.: The Genesis of the Alnö alkaline rocks, 1948.

von Eckermann, H.: Borengite A new ultra-potassic rock from Alnö Island, in: Ark. för Mineral. och Geol. Band 2 Nr 39, 1960.

Vuorinen, J. H.: The Alnö alkaline and carbonatitic complex, east central Sweden - a petrogenetic study, Ph.D. thesis, Stockholm University, http://www.diva-portal.org/smash/get/diva2:195305/FULLTEXT01.pdf, 2005.

Vuorinen, J. H. and Skelton, A. D. L.: Origin of silicate minerals in carbonatites from Alno Island, Sweden: magmatic crystallization or wall rock assimilation?, Terra Nov., 16, 210-215, doi:10.1111/j.1365-3121.2004.00557.x, http://doi.wiley.com/10.1111/j.1365-3121. 2004.00557.x, 2004.

Welin, E.: The U-Pb zircon age of the Rödön rapakivi granite, central Sweden, Gff, 116, 113-114, doi:10.1080/11035899409546169, 1994.

Woolley, A. R. and Church, A. A.: Extrusive carbonatites: A brief review, Lithos, 85, 1-14, doi:10.1016/j.lithos.2005.03.018, http: //linkinghub.elsevier.com/retrieve/pii/S0024493705001064, 2005. 
Solid Earth Discuss., doi:10.5194/se-2017-3, 2017

Manuscript under review for journal Solid Earth

Published: 23 January 2017

(c) Author(s) 2017. CC-BY 3.0 License.

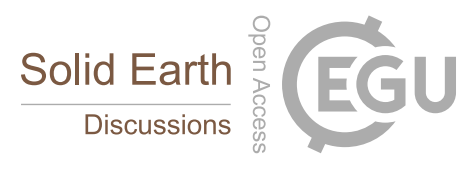

(c) (i)

Woolley, A. R. and Kjarsgaard, B. A.: Paragenetic Types of Carbonatite As Indicated By the Diversity and Relative Abundances of Associated Silicate Rocks: Evidence From a Global Database, Can. Mineral., 46, 741-752, doi:10.3749/canmin.46.4.741, http://www.canmin.org/cgi/ doi/10.3749/canmin.46.4.741, 2008.

Zaitsev, A. N., Terry Williams, C., Jeffries, T. E., Strekopytov, S., Moutte, J., Ivashchenkova, O. V., Spratt, J., Petrov, S. V., Wall, F., Seltmann,

5 R., and Borozdin, A. P.: Rare earth elements in phoscorites and carbonatites of the Devonian Kola Alkaline Province, Russia: Examples from Kovdor, Khibina, Vuoriyarvi and Turiy Mys complexes, Ore Geol. Rev., 61, 204-225, doi:10.1016/j.oregeorev.2014.02.002, http: //dx.doi.org/10.1016/j.oregeorev.2014.02.002, 2014. 
Solid Earth Discuss., doi:10.5194/se-2017-3, 2017

Manuscript under review for journal Solid Earth

Published: 23 January 2017

(c) Author(s) 2017. CC-BY 3.0 License.

Table 1. Summary of the petrophysical measurements from the Alnö complex. Number of samples, $n$, is shown inside parenthesis.

\begin{tabular}{|c|c|c|c|c|c|c|c|c|c|}
\hline \multirow{2}{*}{ Rock } & \multicolumn{3}{|l|}{ Density $\left(\mathrm{kg} / \mathrm{m}^{3}\right)$} & \multicolumn{3}{|l|}{ Susceptibility $(\mu \mathrm{SI})$} & \multicolumn{3}{|c|}{ Remanence $(\mathrm{mA} / \mathrm{m})$} \\
\hline & $\min -\max (\mathrm{n})$ & mean & std dev & $\min -\max (\mathrm{n})$ & mean & std dev & $\min -\max (n)$ & mean & std dev \\
\hline $\begin{array}{l}\text { Carbonatite } \\
\text { (fine- } \\
\text { grained) }\end{array}$ & $2600-3250(15)$ & 2935 & 162 & $400-62000(43)$ & 15105 & 21023 & $1600-20000(7)$ & 4983 & 6868 \\
\hline $\begin{array}{l}\text { Carbonatite } \\
\text { (coarse- } \\
\text { grained) }\end{array}$ & $2710-3090(103)$ & 2848 & 101 & $3-250000(298)$ & 33924 & 44457 & $30-80(4)$ & 51 & 31 \\
\hline Fenite & $2560-3170(37)$ & 2729 & 138 & $100-40000(87)$ & 2010 & 5182 & $10-30(3)$ & 17 & 12 \\
\hline Ijolite & $2600-3070(15)$ & 2883 & 133 & $400-160000(40)$ & 13283 & 33636 & $10-500(6)$ & 132 & 177 \\
\hline $\begin{array}{l}\text { Nepheline- } \\
\text { syenite }\end{array}$ & $2550-2940(33)$ & 2727 & 104 & $300-80000(79)$ & 6207 & 15223 & $40-1150(5)$ & 425 & 458 \\
\hline Pyroxenite & $2990-3430(12)$ & 3243 & 116 & $500-156000(35)$ & 17941 & 42260 & $800-2550(3)$ & 1579 & 891 \\
\hline Breccia & 2750-2990 (11) & 2846 & 80 & not measured & & & not measured & & \\
\hline Alnöite & $2850-2890(9)$ & 2865 & 14 & $500-25000(9)$ & 7643 & 8467 & 10-200 (9) & 71 & 71 \\
\hline Migmatite & $2640-2730(4)$ & 2704 & 28 & $200-300(10)$ & 264 & 39 & $10-20(3)$ & 13 & 6 \\
\hline
\end{tabular}


Solid Earth Discuss., doi:10.5194/se-2017-3, 2017

Manuscript under review for journal Solid Earth

Published: 23 January 2017

(c) Author(s) 2017. CC-BY 3.0 License.

(c) (1)

Table 2. Cell thickness at various depths in the inversion models.

\begin{tabular}{ll}
\hline Depth (m) & Cell thickness (m) \\
\hline $130-0$ & 10 \\
$0-100$ & 20 \\
$100-4250$ & 50 \\
$4250-8350$ & 100 \\
$8350-16660$ & 2770 \\
\hline
\end{tabular}

